
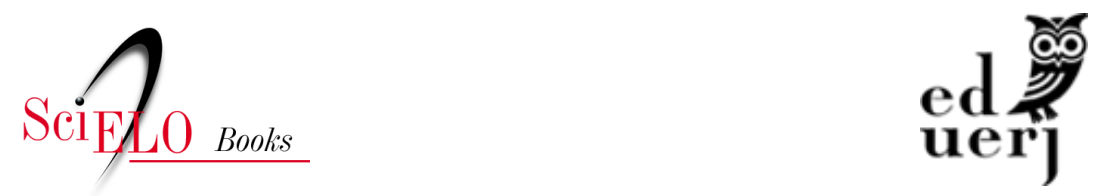

\title{
Capítulo III - A cidade como espaço de intercâmbio cultural, social e político e de protagonismo docente
}

\author{
Angélica Borges
}

\section{SciELO Books / SciELO Livros / SciELO Libros}

BORGES, A. A cidade como espaço de intercâmbio cultural, social e político e de protagonismo docente. In: A urdidura do magistério primário na Corte Imperial: um professor na trama de relações e agências [online]. Rio de Janeiro: EDUERJ, 2021, pp. 219-260. ISBN: 978-65-87949-20-8.

https://doi.org/10.7476/9786587949208.0005.

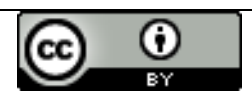

All the contents of this work, except where otherwise noted, is licensed under a Creative Commons Attribution 4.0 International license.

Todo o conteúdo deste trabalho, exceto quando houver ressalva, é publicado sob a licença Creative Commons Atribição 4.0.

Todo el contenido de esta obra, excepto donde se indique lo contrario, está bajo licencia de la licencia Creative Commons Reconocimento 4.0. 


\section{Capítulo III \\ A cidade como espaço de intercâmbio cultural, social e político e de protagonismo docente}

Pesquisas vêm refletindo acerca da participação de professores públicos primários oitocentistas na imprensa pedagógica e nas associaçóes voltadas para o ofício docente, como a Casa Beneficente da Corporação Docente, a Associação Beneficente de Professores Públicos e o Grêmio dos Professores Públicos da Corte, conforme podemos acompanhar pelos estudos de Villela (2000), Schueler (2002), Lemos (2006) e Vicentini e Lugli (2012), entre outros. Não obstante, os professores também estiveram inseridos em outros estabelecimentos, de fins variados, que proporcionaram intercâmbios culturais, sociais e políticos. $\mathrm{O}$ intuito desse movimento de reflexão consiste em discutir a circulação de professores por espaços de sociabilidade, de entretenimento e de reivindicação não relacionados diretamente à escola, mas possivelmente conectados a ela, que permitiram exercer um protagonismo docente e constituir agências e maneiras de se inserir na sociedade.

Nesse sentido, também cabe destacar os estudos de Fonseca (2011 e 2010) para um período mais recuado no tempo. Investigando os professores régios na Capitania de Minas Gerais, Fonseca assinala suas relações com a administração e com as comunidades em que estavam inseridos, suas atividades na docência e em outras instâncias sociais, demonstrando que

[...] também eles foram sujeitos ativos na construção de estratégias de inserção social por meio do letramento e que o exercício dessa profissão foi tanto o seu meio de sobrevivência material quanto ponto de partida para alcance de outras 
posições na sociedade. O magistério régio foi a marca que distinguiu muitos deles e nos oferece mais um caminho de aproximação às vidas desses indivíduos na sua relação com os outros e com a sociedade na qual viviam (2010, p. 18).

De tal forma, da casa para a rua, podemos observar professores públicos e adjuntos participando de variados círculos sociais. Faziam parte de sociedades, institutos, agremiações e congregações. Agustín Escolano (2011) aborda a importância de analisar a gênese e o funcionamento dos círculos e redes de sociabilidade dos professores a fim de compreender "a configuração societária da profissão dos docentes, um aspecto essencial para analisar o desenvolvimento do ofício de ensinar" (p. 23, tradução nossa). ${ }^{1}$ E cita as irmandades, corporações, associações, conferências, centros de colaboração, espaços de prática e imprensa profissional como os lugares em que se formalizou a sociabilidade docente e se difundiu a arte de ensinar. Podemos observar, pelo quadro de instituições e atuações das quais fez parte o professor Pardal, diferentes dimensões das atividades do professor público na Corte em consonância com as questões em debate na época.

Quadro 22 - Instituições e comissões com participação de Pardal

\begin{tabular}{|c|l|l|}
\hline $\mathbf{N}^{\circ}$ & Instituições e comissões & Cargos ocupados \\
\hline 1 & Irmandade do Apóstolo Evangelista São Matheus & Escrivão, secretário (1845 a 1850) \\
\hline 2 & Sociedade Auxiliadora da Indústria Nacional & Sócio efetivo (1847) \\
\hline 3 & Imperial Sociedade Amante da Instrução & Conselheiro, consultor (1847 a 1852) \\
\hline 4 & Sociedade de Baile Guanabara & Diretoria (1852) \\
\hline 5 & Estrada de Ferro Pedro II & Acionista (1855) \\
\hline 6 & Associação Paroquiana de Santana & Conselheiro (1857) \\
\hline 7 & Companhia mútua de seguro de vida de escravos & Comissão (1859) \\
\hline 8 & Sociedade campestre & Secretário (1860) \\
\hline 9 & Academia Pedagógica & Secretário (1860) \\
\hline 10 & Devoção da Nossa Senhora da Madre de Deus & Protetor (1860) \\
\hline 11 & Comissão de professores para “acudir o governo imperial” & Membro (1863) \\
\hline 12 & Caixa Municipal de Beneficência & Encarregado (1863) \\
\hline
\end{tabular}

1 No original: "La configuración societaria de la profesionalidad de los docentes, un aspecto esencial para analizar el desarollo del ofício de enseñar". 


\begin{tabular}{|r|l|l|}
\hline 13 & Club Fluminense & Diretoria $(1867,1868)$ \\
\hline 14 & Comissão de arrolamento da Corte & Membro $(1870)$ \\
\hline 15 & Instituto dos Professores Públicos da Corte & Organizador (1872) \\
\hline 16 & Conferências semanais de professores & Organizador (1872) \\
\hline 17 & Club Mozart & Secretário (1872) \\
\hline 18 & Associação Econômica Auxiliar & Membro (1875) \\
\hline 19 & Sociedade Recreio Dramático Riachuelense & $\begin{array}{l}\text { Conselho, secretário, vice-presidente e } \\
\text { presidente (1876-1885) }\end{array}$ \\
\hline 20 & Associação de Saneamento da Capital do Império & $?(1876)$ \\
\hline 21 & $\begin{array}{l}\text { Comissão para promover donativos para organização da } \\
\text { Escola Normal ou uma escola primária de 2 grau }\end{array}$ & Membro (1878) \\
\hline 22 & Imperial Companhia de Seguro Mútuo Contra Fogo & $\begin{array}{l}\text { Secretário (1878)/ Conselheiro } \\
(1885)\end{array}$ \\
\hline 23 & Comissão contra supressão dos trens do subúrbio & Membro (1882) \\
\hline 24 & Associação Libertadora Visconde do Rio Branco & Presidente (1883) \\
\hline 25 & Irmandade Nossa Senhora da Luz & Definidor (AL, 1882) \\
\hline 26 & $\begin{array}{l}\text { Comissão para agenciar donativos na região de São Fran- } \\
\text { cisco Xavier para as vítimas do terremoto na Espanha }\end{array}$ & Membro (1885) \\
\hline 27 & Comissão para organização de “Bando Precatório" & Membro (1885) \\
\hline
\end{tabular}

Fonte: Quadro elaborado pela autora com base nas informações levantadas nos jornais da Hemeroteca Digital da Biblioteca Nacional e no Almanak Laemmert.

O número de instituições e atuações sociais, econômicas, culturais e religiosas com os quais o professor esteve envolvido é consideravelmente grande. Cabe ressaltar que no quadro constam apenas aquelas que foram noticiadas pelos jornais, pois no procedimento de pesquisa adotado não foi possível avaliar sua participação em outras instituições que não tiveram o privilégio de receber uma nota na imprensa, bem como aquelas nas quais Pardal não ocupava um cargo diretivo. Tal constatação demonstra que o professor era uma pessoa muito ativa socialmente. Circulava por várias esferas sociais, desde a "boa sociedade" do Club Fluminense (Diário do Rio de Janeiro, 23 jan. 1867), até a comissão nomeada por moradores do subúrbio. Opero com a hipótese de que, ao participar desses espaços e ocupar diferentes cargos, Pardal investia em uma carreira pública - possivelmente, na política local -, e exercia um protagonismo docente na sociedade. 
Nesta parte do estudo, pretendo analisar a participação de Pardal em tais instituições e mobilizações conjugada à atuação de outros professores, com intuito de mostrar as dinâmicas e agências desses sujeitos na sociedade, em espaços não escolares, mas inevitavelmente ligados à imagem da escola por meio da pessoa do professor. O levantamento da atuação dos outros professores não foi feito de forma exaustiva e se ateve às participações que se deram, em sua maior parte, por meio da ocupação de cargos diretivos e de mobilizações com publicidade na imprensa, assim como no caso de Pardal.

Em razão do volume de informações e da quantidade de professores que lecionaram nas escolas públicas da Corte no mesmo período que Pardal, foi preciso fazer um recorte. Optou-se por se concentrar o levantamento em torno dos professores públicos homens (apêndice 10), pelo fato dos círculos frequentados por Pardal, assinalados nas fontes pesquisadas, darem maior (ou unicamente) destaque à presença masculina, possibilitando alinhavar a circulação dos mestres, mas dificultando a observação da participação de mulheres, para a qual seria preciso um investimento de pesquisa de maior envergadura. Mas apesar da delimitação, foi possível observar professoras em espaços em que os homens também se faziam presentes, como em cargos diretivos de irmandades - Venerável Congregação das Irmãs de Santa Teresa; Imperial Irmandade de Nossa Senhora da Gloria do Outeiro; Ordem Terceira de São Francisco da Penitência - e em abaixo-assinado, como o feito em testemunha dos trabalhos de limpeza urbana realizado pelo senhor Antônio Nunes de Souza e Comp., cuja única mulher era a professora primária da escola pública da freguesia de Santo Antonio, Amalia Justa dos Passos Coelho (Correio Mercantil, 21 abr. 1859).

Conforme já mencionado, Pereira de Jesus (2013) apresenta uma tipografia de associações que se divide em oito grupos. Como nem todas as atividades exercidas pelos docentes eram de caráter associativista, organizo a análise de forma a articular a classificação de Pereira de Jesus com as agências dos professores na cidade. Assim, para abordar a participação em tais instituições, divido a análise em seis agrupamentos em torno de: vida comunitária; política; associações beneficentes; de socorros mútuos, previdência e seguro; irmandades; e atividades recreativas. Tal organização engloba as associações e sociedades, mas também atividades sem vínculos institucionais. 


\section{Vida comunitária}

Recebemos ontem em nosso escritório a distinta comissão nomeada pelos moradores dos subúrbios, reunidos em meeting solene no dia 17 corrente, e que fora encarregada de agradecer à imprensa que protestou mais energicamente contra a ideia aventuada pelo Sr. Affonso Celso, no senado, sobre a supressão dos trens de subúrbios.

Gazeta da tarde (20 set. 1882)

O professor Pardal era o relator da referida comissão que receava ver os subúrbios despovoados e casas desabitadas que representavam "o capital acumulado à custa de imensos sacrifícios de operários e cidadãos”. Com "eloquentes palavras", o professor, ex-proprietário de escravo, agradeceu ao redator do jornal, o abolicionista José do Patrocínio, pela atitude enérgica de se pronunciar contra a supressão dos trens. Patrocínio agradeceu e respondeu que a Gazeta da Tarde era a "folha do povo" e que não cumpria mais do que seu dever.

Iniciativas populares para reivindicar melhorias para as regióes em que moravam ou em favor de determinados sujeitos pareciam ser bastante comuns e podiam ser frequentemente vistas na imprensa. Os professores, como parte da população, não ficavam alheios às mobilizações. Em alguns casos, o envolvimento da escola e do professor com as mobilizações parecia ser significativo e com bastante proximidade, lançando mão do uso do próprio espaço escolar. $\mathrm{O}$ caso da reunião para organização da Associação de Saneamento da Capital do Império ilustra bem a situação ( $O$ Globo, 20 out. 1876). O evento ocorreu em 15 de outubro de 1876, na Escola Municipal São José, e contou com a presença de inúmeras pessoas, dentre as quais alguns professores como Pardal (diretor da escola) e Carlos Augusto Soares Brazil.

A organização dessa associação emergia a partir de um ponto de vista higienista que, diante das condiçóes da cidade naquele momento, conclamava reação urgente da população, pois considerava "impossível permanecer por mais tempo indiferente ao espetáculo contristador que cada ano vai progressivamente apresentando a capital do Império debaixo do ponto de vista sanitário" ( $O$ Globo, 20 out. 1876). O discurso de abertura da sessão, proferido pelo médico Franklin do Amaral, remetia aos dados produzidos por um dispositivo que igualmente contou com a participação de professores: o recenseamento da população. Tal recenseamento não consistia em uma iniciativa da população, mas estava rela- 
cionado a ela. O procedimento também fez uso do espaço escolar, pelo menos no caso da comissão de arrolamento responsável pelo recenseamento do $2 .^{\circ}$ distrito da freguesia de Santana da qual Pardal foi presidente. Sua primeira reunião ocorreu no Largo da Imperatriz, n. ${ }^{\circ} 125$, endereço da escola da freguesia de Santa Rita (Diário do Rio de Janeiro, 10 abr. 1870).

Outros professores também estiveram envolvidos com as atividades de recenseamento, como Amando de Araújo Cintra Vidal, membro da comissão de recenseamento da Corte da freguesia de Inhaúma (Diário de Notícias, 12 jun. 1872); Francisco Alves da Silva Castilho, na freguesia de Campo Grande (Diário de Notícias, 12 jun. 1872); João Correa dos Santos, na freguesia da Ilha do Governador (Diário de Notícias, 12 jun. 1872) e João Marciano de Carvalho, responsável pela freguesia de Santa Cruz (AGCRJ, códice 10.4.19, f. 82).

Não obstante Franklin Amaral apontar a existência de acusações de inexatidão e falsidade acerca dos resultados do censo defende que o trabalho foi, em boa parte das freguesias, "tão completo" quanto deveria ser e ressalta que estavam em sua direção "pessoas bem intencionadas, que rodearam-se de bons auxiliares” ( $O$ Globo, 20 out. 1876).

A nomeação de professores públicos entre os convocados para trabalhar no censo se insere bem na perspectiva levantada por Mattos (2004), já assinalada, dos professores como peças estratégicas na administração pública e construção do Estado; e também em uma ideia inspirada na análise de Carvalho (2007) de que a circulação por diferentes postos da administração pública conferia experiência política aos sujeitos. Embora se trate de proporções distintas, a atuação de professores em atividades locais dava a eles uma experiência local e publicidade de sua imagem que poderiam ser usadas em situações políticas.

A condição dos professores que os permitia estar em maior "contato com o povo”, como disse o professor Brazil, colocava a figura do professor como agente em potencial para realizar este tipo de tarefa, considerando que ele já conhecia uma parte da população via escola. Cabe destacar que Franklin do Amaral relatou que alguns habitantes se recusaram a fornecer a lista da família e que os "agentes do censo" recorreram aos vizinhos para obter as informações.

A população também foi mobilizada quando o professor Pardal foi convocado para auxiliar em outra atividade, de caráter cívico e festivo: a organização dos festejos adotados pela Câmara Municipal para comemorar a "vitória decisiva dos exércitos aliados na República do Paraguai” (Câmara Municipal, 1868). A Câmara convocou os moradores a iluminarem a frente de suas casas por três dias 
e nomeou comissões para enviarem esforços para a montagem de arcos triunfais, artefatos e iluminação nos locais públicos durante os dias festivos.

A vizinhança também poderia se reunir para dar apoio ou reconhecimento a alguém pela prestação de um serviço de interesse na localidade, como no caso de um empresário de barcas na freguesia de São Cristóvão (Correio Mercantil, 18 jul. 1852; Diário do Rio de Janeiro, 20 jul. 1852). Os moradores, entre eles os professores Joaquim Sabino Pinto Ribeiro e João Ferreira Moscoso, fizeram um abaixo-assinado dirigido ao governo imperial em que narram que um "empreendedor montou a expensas suas uma carreira regular de barcas”, havia mais de três anos, com saídas de São Cristóvão e da Prainha, no centro de cidade, com horas certas e preços módicos. Para "bem servir ao público", construiu também com suas expensas uma ponte de embarque. No entanto, os moradores alegavam que os outros donos de barcos tomados pela inveja, em vez de se reunirem para também construírem suas pontes, resolveram disputar a do empresário:

[...] invocando o termo de concessão lavrado pela capitania do porto para a construção dessa ponte, entendendo-o no seu mais amplo sentido, determinaram essa autoridade a mandar que a todo mundo, ao gozo e ao estrago que todos quisessem causar, fosse entregue a ponte pelo empresário construída (Correio Mercantil, 18 jul. 1852).

Devido à concorrência e às despesas com consertos e reparos na manutenção, o empresário suspendeu o serviço e, dessa forma, segundo os signatários, a ponte ia se arruinando, perdendo a empresa e, não menos, os moradores. $\mathrm{O}$ documento relata que o empresário havia requerido ao governo a concessão de propriedade de ponte, comprometendo-se "a conservá-la em perfeito estado de asseio, e a manter pelo ínfimo preço de estilo a carreira regular estabelecida, concedendo todavia aos botes de ganhos o gozo de desembarque na lingueta de pedra em que começa a ponte."

Diante disso, os moradores fizeram um abaixo-assinado de apoio ao pedido do empresário para que lhe fosse concedida a propriedade. A lista de assinaturas é bastante extensa e mostra que houve uma grande mobilização dos moradores em favor do empresário. Não foi possível saber como se deu a iniciativa, mas ela demonstra a organização da população e a agência coletiva que contava com professores em suas fileiras, a elaboração de estratégia que requeria uma participação de maior número de pessoas possíveis - o abaixo-assinado -, e sua divulgação na imprensa. 
Outra ação de reconhecimento, mas de caráter individual, envolveu três professores públicos primários, em épocas distintas, a respeito do tratamento oferecido pelo médico Ricardo Kirk. O reconhecimento funcionava como demonstração de agradecimento público, mas também como propaganda do médico e do produto na sociedade carioca. Francisco Joaquim Nogueira Neves foi o primeiro localizado em agradecimento ao médico que curou doença do seu filho que há nove anos sofria de grande inflamação nas duas pernas. $\mathrm{O}$ tratamento se deu por meio de chapas medicinais em espaço de um ano: "Com quanto o dito Sr. fosse satisfeito com o diminuto estipêndio que recebeu do seu trabalho; eu seria falto de reconhecimento, se não conhecesse o grande benefício de que lhe sou devedor" (Diário do Rio de Janeiro, 04 jul. 1843).

O mesmo reconhecimento da eficácia no tratamento com as "chapas medicinais" de Ricardo Kirk pode ser visto nos casos de Joaquim Sabino Pinto Ribeiro, que atesta que sua esposa, depois de longo tratamento alopático sem resultados, achava-se plenamente restabelecida (Correio Mercantil, 04 nov. 1858); e de Joaquim José Cardoso de Siqueira Amazonas, que publicou nota em dois momentos distintos (Diário do Rio de Janeiro, 19 mar. 1857, e Correio Mercantil, 21 out. $1865)$. No primeiro anúncio, datado de 1857 , o professor Joaquim, “abaixo-assinado, facultativo pela imperial Academia de medicina, médico-cirúrgica desta Corte", alerta para o cuidado de não confundi-la com outras chapas preconizadas por ocasião da epidemia de cólera. $\mathrm{Na}$ segunda nota, o professor que, também era médico, apontava as vantagens obtidas no tratamento da própria saúde, mais especificamente nas "inflamações no estômago, fígado, baço, etc, ainda que sua eficácia se estenda às lesões de outros órgãos”. Apesar do reconhecimento, cabe destacar que o professor faleceu menos de um ano depois, em 26 de abril de 1866. Observa-se que o professor tinha agências de caráter profissional de dois tipos bastante diferentes, a docência e a médica.

Outra atividade que tinha relação com a localidade e da qual também fizeram parte professores primários ocorreu em associações locais que, pelas fontes encontradas, também sugeriam ter um caráter político, como a Associação Parochiana da freguesia de Santana, da qual Pardal foi conselheiro em 1857 ( $O$ Correio da Tarde, 31 mar. 1857). A reunião prevista para sua inauguração se daria em 14 de abril de 1857, nos salóes do Museu Nacional (Diário do Rio de Janeiro, 14 abr. 1857). O lugar da reunião evidencia que a associação parecia ser de grande porte e reuniria muitas pessoas. 
O professor Francisco Alves da Silva Castilho também era membro de uma associação que chama bastante atenção pelo nome: "Sociedade Beneficente e Propagadora dos direitos dos cidadãos da freguesia de Campo Grande”. A nota de jornal, ao tratar de suas primeiras realizações, já aponta as intrigas entre tais tipos de associações e a política local. Parecia ter a intenção de provar a veracidade dos objetivos da sociedade e da atuação do grupo, "tapar a boca da maledicência ou fazer emudecer aos incrédulos”, frente à descrença em torno de tais instituições que estariam ligadas às desgraças dos "desfavorecidos da fortuna”, ocasionadas pelo "inocente exercício do mais importante dos seus direitos constitucionais, isto é, o de votar nas eleições primárias” (Correio da Tarde, 28 jan. 1860). O texto atrela os direitos dos cidadãos ao direito de votar nas eleições, aspecto destacado por Mattos quando discute que a Constituição de 1824, ao reconhecer os direitos civis dos cidadãos brasileiros, diferenciou-os em função de suas posses por meio do voto censitário em três gradações: "o cidadão passivo (sem renda suficiente para ter direito a voto), o cidadão ativo votante (com renda suficiente para escolher, através do voto, o colégio de eleitores), e o cidadão ativo eleitor e elegível” (2000, p. 20-21). A palavra "propagadora” trazida no nome da sociedade poderia sugerir a ideia de ajudar aos "cidadãos passivos" a se tornarem ativos por meio dos auxílios fornecidos pela instituição. As críticas dirigidas a esse tipo de associação poderia sugerir igualmente que tal auxílio seria movido por interesses eleitoreiros.

No entanto, entre os exemplos usados para comprovação de que seguia seus estatutos, situam-se a ajuda aos enfermos e a entrega de esmolas. Para ilustrar que a sociedade estava "ocupando-se com negócios importantes em benefício da freguesia", o artigo menciona a proposta do professor Castilho acerca da necessidade de escolas particulares nos pontos da freguesia que estavam fora do alcance da escola pública:

Esta proposta, que foi acolhida com geral aplauso, tem por objetivo uma representação promovida pela sociedade, pedindo ao governo medidas que facilitem o ensino particular nos pontos afastados da escola pública a todos que puderem dar à mocidade os elementos mais indispensáveis da instrução pública.

Embora o texto não informe quais eram as medidas que reivindicavam ao governo, é possível inferir que ela se desse por meio da subvenção de escolas particulares para o ensino de crianças pobres. O professor também ofereceu à 
sociedade seus serviços em benefício da instrução de adultos. A presença de um professor como sócio da instituição, que fazia propostas para melhorar o ensino na localidade, corroborava a legitimação das atividades da sociedade - que poderia ser também usar a instrução como meio para "propagar direitos dos cidadãos" da freguesia -, bem como fortalecer o nome de Castilho como eleitor, como coincidentemente ocorreu em 1861, no ano seguinte ao da fundação da sociedade.

O conjunto de casos levantados mostram as agências de professores na vida local no sentido de conseguir melhorias urbanas para a região, dar apoio a atividades de determinados sujeitos e lançar mão de sua imagem de professor para ajudar a legitimar agências coletivas. As ações de instituições como a Sociedade Beneficente e Propagadora dos Direitos dos Cidadãos da freguesia de Campo Grande mostram que as atuações locais também poderiam estar ligadas aos processos eleitorais, analisados a seguir.

\section{Política: "Não são esses cidadãos a atividade e o centro do partido nas suas localidades?"}

... mandai ao parlamento quem, em vossa consciência, possa, pelos seus comprovados talentos, ilustração, probidade e elevadíssimo caráter, promover a resolução do magno problema de nossa vida social.

Carta dos professores aos eleitores do $1 .{ }^{\circ}$ Distrito da Corte (1881)

A Carta de 1881 era um texto de campanha para eleição de Carlos Leôncio de Carvalho que, dois anos antes, havia promovido a reforma da instrução na Corte e do ensino superior em todo o Império. Assinavam a carta 58 professores, de nível superior, como os da Faculdade de Medicina; do ensino secundário, como os do Colégio Pedro II; e do ensino primário: Frazão, Sabino, Lisboa, Cony, Póvoas Pinheiro, Carneiro, Augusto Amazonas, Gustavo Alberto e Gomes da Silva (Gazeta de notícias, 30 out. 1881). A carta foi publicada durante vários dias e demonstrava o empenho de uma categoria profissional, de diferentes níveis de ensino, na eleição de um sujeito do Partido Liberal em torno do qual nutriam esperanças de melhorias na área educacional. Interessante destacar que Leôncio de Carvalho, anos antes, enquanto Ministro do Império, havia afirmado em seu relatório que os professores públicos não deveriam se envolver "nas lutas de que é arena a política” (Relatório do Ministro do Império de 1877, p. 24), o que serve para ilustrar que as posições políticas poderiam ser mais provisórias, de acordo 
com os jogos e disputas em cena, do que constituir arranjos rígidos ou inegociáveis nas tramas eleitorais.

A atuação dos professores na política não ficava restrita aos discursos e abaixo-assinados de apoio. Também havia uma atuação ativa como votante, eleitor, candidato ou membro partidário, conforme podemos observar no quadro a seguir.

Quadro 23 - Professores no cenário político-eleitoral

\begin{tabular}{|c|c|c|c|}
\hline $\mathbf{N}$. & Professor & $1^{\text {a }}$ aparição & Condição \\
\hline 1 & Venancio José da Costa & 1847 & $\begin{array}{l}\text { Votante de Paquetá (Gazeta Oficial do Império } \\
\text { do Brasil, } 25 \text { jan. 1847). }\end{array}$ \\
\hline 2 & Candido Matheus de Faria Pardal & 1850 & Suplente de eleitor; eleitor; e vereador (?) \\
\hline 3 & $\begin{array}{l}\text { Marcos Bernardino da Costa } \\
\text { Passos }\end{array}$ & 1850 & $\begin{array}{l}\text { Suplente de eleitor do Engenho Velho (Diário } \\
\text { do Rio de Janeiro, } 21 \text { jan. 1850). }\end{array}$ \\
\hline 4 & Joaquim Sabino Pinto Ribeiro & 1860 & $\begin{array}{l}\text { Votante, nota pedindo voto para o cargo de } \\
\text { eleitor (Correio Mercantil, } 29 \text { out. 1856); eleitor } \\
\text { de São Cristóvão (Correio Mercantil, 29 dez; } \\
\text { 1860); candidato a eleitor pela chapa governista } \\
\text { (Diário do Rio de Janeiro, } 05 \text { jan. 1861). }\end{array}$ \\
\hline 5 & Luiz Thomaz de Oliveira & 1856 & $\begin{array}{l}\text { Candidato a eleitor no engenho velho (Correio } \\
\text { Mercantil, } 25 \text { out. 1856); suplente de eleitor } \\
\text { (Diário do Rio de Janeiro, } 10 \text { nov. 1856). }\end{array}$ \\
\hline 6 & $\begin{array}{l}\text { Antonio Cypriano de Figueiredo } \\
\text { Carvalho }\end{array}$ & 1856 & $\begin{array}{l}\text { Candidato a eleitor da freguesia de Santana, } \\
\text { com discurso político (Correio mercantil, } 20 \\
\text { out. 1856); Votante (Diário do Rio de Janeiro, } \\
26 \text { jan. 1877). }\end{array}$ \\
\hline 7 & $\begin{array}{l}\text { Antonio Pinto da Costa de Souza } \\
\text { Brandão }\end{array}$ & 1859 & $\begin{array}{l}\text { Escrutador da mesa eleitoral de Inhaúma (Cor- } \\
\text { reio Mercantil, } 19 \text { jan 1859). }\end{array}$ \\
\hline 8 & $\begin{array}{l}\text { Joaquim José Cardoso de Siqueira } \\
\text { Amazonas }\end{array}$ & 1860 & $\begin{array}{l}\text { Eleitor da freguesia de São Cristóvão (Diário do } \\
\text { Rio de Janeiro, } 10 \text { ago. 1860). }\end{array}$ \\
\hline 9 & José Bernardes Moreira & 1860 & $\begin{array}{l}\text { Votante da freguesia de Santana (Correio da } \\
\text { Tarde, } 11 \text { maio 1860). }\end{array}$ \\
\hline 10 & Francisco Alves da Silva Castilho & 1861 & $\begin{array}{l}\text { Eleitor pela freguesia de Campo Grande (Diá- } \\
\text { rio do Rio de Janeiro, } 12 \text { jan. 1861). }\end{array}$ \\
\hline 11 & João Marciano de Carvalho & 1863 & $\begin{array}{l}\text { Eleitor pela chapa progressista da freguesia de } \\
\text { Santa Cruz (Diário do Rio de Janeiro, } 12 \text { ago. } \\
\text { 1863). }\end{array}$ \\
\hline 12 & Joaquim Antonio da Silva Bastos - & 1863 & $\begin{array}{l}\text { Eleitor do partido progressista da freguesia de } \\
\text { Guaratiba (Diário do Rio de Janeiro, } 14 \text { ago. } \\
\text { 1863). }\end{array}$ \\
\hline
\end{tabular}




\begin{tabular}{|c|c|c|c|}
\hline 13 & Manoel José Pereira Frazão & 1868 & $\begin{array}{l}\text { Suplente de eleitor da freguesia da Glória (Cor- } \\
\text { reio Mercantil, } 24 \text { jul. 1868). }\end{array}$ \\
\hline 14 & Jose Joaquim Pereira de Azurara & 1869 & Eleitor da freguesia de Guaratiba (AL, 1869). \\
\hline 15 & Gustavo José Alberto & 1876 & $\begin{array}{l}\text { Lista de qualificação de votantes, } 38 \text { anos, } \\
\text { casado (Diário do Rio de Janeiro, } 15 \text { jul. 1876). }\end{array}$ \\
\hline 16 & Carlos Augusto Soares Brazil & 1876 & $\begin{array}{l}\text { Lista de qualificação de votantes, } 37 \text { anos, } \\
\text { casado (Diário do Rio de Janeiro, } 15 \text { jul. 1876). }\end{array}$ \\
\hline 17 & Augusto Candido Xavier Cony & 1876 & $\begin{array}{l}\text { Lista de qualificação de votantes, } 33 \text { anos, } \\
\text { casado, filho de Diego José Cony (Diário do } \\
\text { Rio de Janeiro, } 14 \text { jul. 1876); eleitor da fregue- } \\
\text { sia de Santana (AL, 1878). }\end{array}$ \\
\hline 18 & José Alves da Visitação & 1877 & $\begin{array}{l}\text { Lista de qualificação de votantes, } 24 \text { anos, } \\
\text { solteiro, filho de Joaquim Alves da Visitação } \\
\text { (Diário do Rio de Janeiro, } 22 \text { jan. 1877). }\end{array}$ \\
\hline 19 & Januário dos Santos Sabino & 1877 & $\begin{array}{l}\text { Lista de qualificação de votantes, } 39 \text { anos, casado } \\
\text { (Diário do Rio de Janeiro, } 09 \text { fev. 1877); eleitor } \\
\text { da freguesia de Santana (AL, 1880). }\end{array}$ \\
\hline 20 & José Theodoro Burlamaque & 1877 & $\begin{array}{l}\text { Lista de qualificação de votantes, } 44 \text { anos, sol- } \\
\text { teiro (Diário do Rio de Janeiro, } 19 \text { fev. 1877). }\end{array}$ \\
\hline 21 & Joaquim José de Souza Ribeiro & 1877 & $\begin{array}{l}\text { Votante (Diário do Rio de Janeiro, } 28 \text { jun. } \\
\text { 1877). }\end{array}$ \\
\hline 22 & João Pedro dos Santos Cruz & 1877 & $\begin{array}{l}\text { Lista de qualificação de votantes, } 35 \text { anos, } \\
\text { casado (Diário do Rio de Janeiro, } 18 \text { jan. 1877). }\end{array}$ \\
\hline 23 & Amando de Araújo Cintra Vidal & 1877 & $\begin{array}{l}\text { Lista de qualificação de votantes, } 36 \text { anos, } \\
\text { casado (Diário do Rio de Janeiro, } 16 \text { jan. 1877). }\end{array}$ \\
\hline 24 & $\begin{array}{l}\text { Carlos Antonio Coimbra de } \\
\text { Gouvea }\end{array}$ & 1877 & $\begin{array}{l}\text { Lista de qualificação de votantes, } 28 \text { anos, } \\
\text { casado (Diário do Rio de Janeiro, } 21 \text { jan. 1877). }\end{array}$ \\
\hline 25 & José João de Povoas Pinheiro & 1877 & $\begin{array}{l}\text { Lista de qualificação de votantes, } 26 \text { anos, sol- } \\
\text { teiro (Diário do Rio de Janeiro, } 21 \text { jan. 1877). }\end{array}$ \\
\hline 26 & Olympio Catão Viriato Montez & 1877 & $\begin{array}{l}\text { Lista de qualificação de votantes, } 36 \text { anos, } \\
\text { casado (Diário do Rio de Janeiro, } 03 \text { mar.1877); } \\
\text { Presidente da mesa paroquial das eleições para } \\
\text { vereador (O Cruzeiro, } 23 \text { fev. 1878). }\end{array}$ \\
\hline 27 & João Ferreira Moscoso & 1878 & $\begin{array}{l}\text { Eleitor da chapa liberal (Diário do Rio de Janeiro, } \\
09 \text { ago. 1878); Constava na lista da chapa liberal } \\
\text { da freguesia do Espírito Santo (A Reforma, } 03 \\
\text { ago. 1878); eleitor da freguesia do espírito Santo } \\
\text { (Diário do Rio de Janeiro, } 09 \text { ago. 1878). }\end{array}$ \\
\hline
\end{tabular}

Fonte: Quadro elaborado pela autora com base nas informaçôes levantadas nos jornais da Hemeroteca Digital da Biblioteca Nacional e no Almanak Laemmert.

O quadro 22 não representa uma pesquisa exaustiva dos nomes dos professores nos periódicos em razão dela estar centralizada na investigação do professor 
Pardal. Portanto, outros professores que não estão citados no quadro também poderiam estar envolvidos com as eleições.

Conforme mencionado, o "votante" era aquele que, participando das eleições primárias, elegia o chamado "eleitor". Deveria possuir uma renda de 200 mil réis (fato que tecnicamente permitiria a todos os professores homens serem votantes) e não havia exigência de saber ler e escrever até 1881. A lista de qualificação de votantes publicada nos jornais é um documento muito rico, pois apresenta uma espécie de currículo pessoal sucinto, informando nome, filiação, idade, "estado civil", instrução, renda e profissão. Vários professores foram encontrados em tais listas, demonstrando que eles se interessavam por questões políticas ou que eram cooptados para participarem das eleições. De uma forma ou de outra, o envolvimento, ainda que no âmbito das eleições primárias, torna-se evidente.

No caso dos eleitores, era exigida renda de 400 mil réis e precisavam ser eleitos pelos votantes. Pardal e Marcos Bernardino (que ainda não era professor público à época) são os professores mais antigos encontrados como eleitores, ambos na condição de suplentes, em 1850. Observa-se que os professores eleitores identificados no quadro eram de diferentes freguesias, entre urbanas e rurais, e ao atuarem nos processos eleitorais, ajudavam a configurar o cenário político da época.

Havia professores ligados ao Partido Progressista, ao Liberal e ao Conservador, o que demonstra que não existia somente uma posição política no interior da categoria e nem que isso impedisse os professores de grupos políticos diferentes de agirem juntos em prol da classe. Apesar das rivalidades no interior do magistério público primário, evidenciados pela imprensa pedagógica (Villela, 2002b), havia uma tentativa de passar uma imagem de união do grupo, aspecto que fica evidente em artigo da folha $A$ verdadeira Instrução Pública - presidida por Manoel Frazão e dirigida por comissão composta por Pardal e mais alguns professores -, que rebatia as suspeitas de dissidência.

Por outro lado blasonam de ter ao seu lado os distintos professores Costa e Cunha, e Castilho, dos quais fazem apologia.

Mas, que querem inferir do fato de escreverem esses ilustres professores de preferência na Instrução Pública? Que são nossos inimigos, ou que estão em dissidência? Forte ingenuidade! Pois nós interpretamos a coisa de outro modo. Esses dignos cavalheiros não querem que suas asserções sejam apreciadas como são as nossas; lá nisso eles fazem justiça ao caráter de nossos adversários. 
E depois, se o ter escrito na Instrução Pública significasse dissidência, então nosso companheiro de lide, o ilustre professor Marques, seria também dissidente!

Ora, meus amigos, outro ofício! Estamos mais unidos do que nunca o estivemos! (A verdadeira Instrução Pública, 15 jul. 1872)

O recado dirigido à folha $A$ Instrução Pública, embora não trate de questões partidárias, aponta as tensões políticas existentes entre os membros dos jornais. No entanto, a redação de $A$ Verdadeira Instrução Pública parecia cuidar para não serem interpretadas como enfraquecimento da categoria, em um momento em que estavam ganhando terreno e mais visibilidade nos debates da época. Os professores admitiam a existência de discordâncias, mas não de dissidências. E alfinetavam: não eram "políticos" que falavam de educação, eram do ofício docente; por isso, mais unidos do que nunca. Mas, se não admitiam a existência de intrigas internas na categoria, o mesmo não se dá no caso dos grupos políticos nos quais os professores também circulavam e cujas tramas surtiam efeitos no exercício docente. Nesse sentido, cabe lembrar a exoneração de Polycarpo José Dias da Cruz do cargo de professor público primário e a de Pardal do cargo do diretor das escolas municipais por motivos políticos.

Para se inserirem na política via eleição de segundo grau, alguns professores apelavam para algumas estratégias como publicar nota nos jornais para votar, ser votado e agradecer votos. O professor da escola pública de Inhaúma em 1856, Joaquim Sabino Pinto Ribeiro, pode servir de exemplo para os dois primeiros. A estratégia discursiva do professor é bastante interessante e pode ser vista na nota publicada em 29 de outubro 1856, intitulada "Candidatura ao honroso e popular encargo de eleitor!". Os adjetivos chamam a atenção: "honroso" e "popular", dando a ver as representações em torno do cargo. O professor informa que ainda havia vaga na sua lista para votar em eleitor e pede, a fim de que os candidatos não fiquem lhe devendo favores, para que também votem nele, usando como argumento de valorização e legitimidade da candidatura o fato de morar há dezoito anos na freguesia. Apelava para a tradição de se confiar em quem não era "forasteiro". 
Figura 27 - Nota sobre a candidatura de Joaquim Sabino

\section{Candidatura ao Jomrogo o popular} encargo de eleltor:

O abaixo assignado tem a honra de lembrar a seus amigos candidatos ao eleitorado da freguezia do Engrenho Velho, e que até agora lhe nũo communicárão o seu desejo a respeito, que ainda ha logar na sua lista para admissão de alguns nomes ; portunto podem maudar até sabbado $1^{\circ}$ de nobembro, os seus enderecos. E para the nāo ficarem em obrigaçũo, pede-lhes em seu favor o seu voto para o referido encargo desta mesma freguezia, onde o abaixo assignado é domiciliario ha 18 annos.

$$
\text { Joaquim Sabino Pinto Ribeiro. }
$$

S. Christovĩo, 28 de outubro de 1856.

Fonte: Correio Mercantil, 29 out. 1856, Biblioteca Nacional.

No caso de Francisco Alves da Silva Castilho, da freguesia de Campo Grande, o professor publica nota agradecendo aos "comparoquianos" e aos amigos que se empenharam na sua candidatura a eleitor (Correio Mercantil, 27 jan. 1861), demonstrando que havia uma rede de relações que o permitiu sustentar uma candidatura a eleitor na freguesia rural onde residia e trabalhava como professor. Agradece também aos adversários da chapa pela bondade, delicadeza e cavalheirismo com que foi tratado. O tom de agradecimento pode sugerir a existência de tensões produzidas por disputas no interior da própria chapa que poderiam ter sido amenizadas no caso de Castilho. 
Figura 28 - Agradecimentos de Castilho

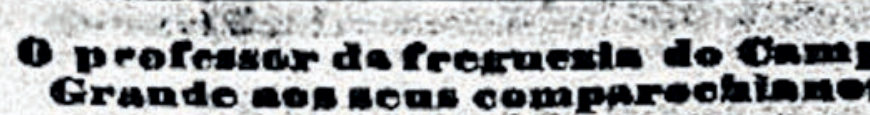

Nío só por me năo ser passivel dirigit-me possonl. mente a todos os mens comparochianos que me honrdrão com o sen roto para eldilor da freguez ia do CampoGrande, como porquo desejo dar um poblico testemunho do mea agradecimento para com os amigos que favoravelmente tomárä́o o empenho de sustentarem minha candidatura, declaro que tenho na mais subida considerağa 2. honra ofavor que de todos recebi nesta eleiça; $\theta$ ainda mesmo aos adversatios da chapa por que fui apresontado campre-mo agradecer toda a bondade, delicadeza - cavalheirismo com que fai tratado duranto o curso da eleiš̃o.

\section{Fanxcisco Alyes da Silya Castilao.}

Este artigo, datado do dia 9 do corrente, não tendo sido ate hojo publicado por, esquecimento do quem me tinha feito o favor do leva-lo á ty pographia, é de novo enviado em 21 de janeiro de 1801 .

Fonte: Correio Mercantil, 27 jan. 1861, Biblioteca Nacional.

Por outro lado, notas de jornais acerca de fraudes eleitorais também poderiam trazer nomes de professores. Em uma delas, menciona-se que o professor Joaquim Antonio da Silva Bastos reclamou de irregularidade na eleição de 1878, pelo fato da mesa ter deliberado a favor de um pedido, feito no próprio dia das eleições, de dezessete votantes para votar (O Cruzeiro, 1878). O problema veio à tona com o sumiço de duas folhas de votantes que não haviam comparecido, cuja culpa recaía em torno de quatro ou cinco dissidentes "despeitados pelo malogro de suas pretensões". Embora o artigo não acuse o professor pelo sumiço, o fato de Joaquim Bastos ter reclamado, mas não ter apresentado o "protesto" formalmente, como havia declarado, poderia tê-lo colocado no rol dos suspeitos ou ao menos ter favorecido o evento ao repassar informações. 
Pardal era eleitor pela freguesia de Santana, mesma freguesia onde mais tarde outro professor, Augusto Candido Xavier Cony, aparecerá nas listagens de eleitores. Nas eleições de 1872, a apuração dos votos pôde ser acompanhada diariamente pelos jornais e o resultado final apontou Pardal em $6 .^{\circ}$ lugar com 736 votos, sendo que o primeiro colocado obteve 751 , diferença muito pequena, deixando para trás um Visconde (de Itamaraty) e o Conselheiro Antonio Félix Martins (seu "chefe" no Conselho Diretor da Inspetoria Geral de Instrução). Dias depois, o jornal publica a "ultima e definitivamente [lista] adotada pelos conservadores da mesma freguesia” em que Pardal aparece em 10. lugar (Correio do Brazil, 09 nov. 1872). Muitos dos votos que o professor primário recebeu podem ter sido conquistados por transitar e ganhar visibilidade em diferentes organizações sociais. Essa pode ter sido a última eleição em que Pardal foi candidato a eleitor pela freguesia de Santana.

A informação de que Cony era eleitor pela freguesia de Santana foi localizada no Almanak Laemmert de 1878, período em que Pardal já havia alterado seu domicílio eleitoral, por ter mudado sua residência para o Engenho Novo. No entanto, a filiação partidária de Cony era outra. A Gazeta da Tarde (20 abr. 1882) noticiou que o eleitorado liberal da paróquia de Santana, sob a presidência do médico, político, ex-presidente da Câmara Municipal, Adolpho Bezerra de Menezes, elegeu para o diretório do Partido Liberal cinco indivíduos, sendo um deles Augusto Candido Xavier Cony. Cony dividia a responsabilidade com o médico Pedro Borges Leitão, o tenente Joaquim Duarte do Nascimento (AL, 1880), o médico e vereador Amaro Manoel de Moraes (AL, 1880) e Antonio Joaquim Lázaro Ferreira, amanuense da Junta Central de Higiene Pública (AL, 1880) - os dois últimos, juízes de paz da freguesia de Santana (AL, 1880). Um professor público primário, um militar, um empregado público e dois médicos agindo juntos em nome do Partido Liberal na localidade, na qual Pardal atuou por vários anos pelo Partido Conservador. Tal fato sinaliza a agência de professores em atividades partidárias locais também como representantes de partidos.

Cony igualmente atuou vários anos junto ao Partido Liberal. Podemos ver seu nome ainda como membro do diretório local em 1889, em um texto que comenta disputas e divergências no interior do Partido. $\mathrm{O}$ artigo escrito por Henrique Alves de Carvalho - que se defendia da intenção de um correligionário de retirá-lo da disputa nas eleições -, faz uma lista dos membros dos diretórios paroquiais do Partido Liberal, na qual consta o nome de Cony, que teriam apoiado sua candidatura. Uma observação que Henrique faz ao final da listagem 
chama atenção: "Não são esses cidadãos a atividade e o centro do partido nas suas localidades?" (Gazeta da Tarde, 10 jul. 1889). A observação data do último ano do Império e pode evidenciar um longo processo de atuações diversas - e até controversas - junto às localidades, contando com professores em suas fileiras.

A mesma freguesia de Santana teve ao longo de três décadas sempre um professor público primário na condição de eleitor, contribuindo para a configuração política das instâncias de governo e das disputas locais. Embora Pardal e Cony fossem ligados a partidos opostos, a rivalidade política não se traduzia em desavenças pessoais. Cony e Pardal, por exemplo, adotaram experiências pedagógicas similares, como a apropriação do sistema Rapet, e notas na imprensa registram elogios de Cony ao trabalho de Pardal.

Na década de 1880, quando residia no Engenho Novo, Pardal apareceu em uma lista publicada em jornal na condição de vereador ( $O$ Paiz, 02 set. 1885). A nota informava que os vereadores haviam entregado ao tesouro da Câmara Municipal uma quantia "agenciada” na freguesia do Engenho Novo. Essa foi a única menção encontrada ao posto de vereador ocupado por Pardal durante a pesquisa, não sendo possível obter mais informações acerca do fato ou verificar se a nota havia incorrido em erro ao incluir o nome de Pardal. A lista de vereadores publicada pelo Almanak Laemmert nesse período não traz o nome de Pardal, por exemplo. Todavia, a possibilidade de eleição de um professor jubilado para um cargo mais alto nos processos eleitorais poderia sugerir a conquista/construção de uma importância e imagem pública ao longo da sua trajetória no cenário carioca.

Outro cargo que estava relacionado às eleições era o de juiz de paz, eleito nas eleições de segundo grau, juntamente com os vereadores. A reforma do Código do Processo Criminal em 1841 limitou os seus poderes, mas sua figura continuou representando uma autoridade local de controle social. Os incisos do artigo 91 do Código que se referem ao papel do juiz de paz eram:

$\$ 4^{\circ}$ Fazer por em custodia o bêbedo, durante a bebedice.

$\$ 5^{\circ}$ Evitar as rixas, procurando conciliar as partes; fazer que não haja vadios, nem mendigos, obrigando-os a viver de honesto trabalho, e corrigir os bêbedos por vicio, turbulentos, e meretriz escandalosas, que perturbam o sossego público, obrigando-os a assignar termo de bem viver, com cominação de pena; e vigiando sobre seu procedimento ulterior.

$\$ 6^{\circ}$ Fazer destruir os quilombos, e providenciar a que se não formem.

$\$ 7^{\circ}$ Fazer auto de corpo de delito nos casos, e pelo modo marcados na lei. 
$\$ 9^{\circ}$ Ter uma relação dos criminosos para fazer prende-lo, quando se acharem no seu distrito $[\ldots]$.

$\$ 14^{\circ}$ Procurar a composição de todas as contendas, e dúvidas, que se suscitarem entre moradores do seu distrito, acerca de caminhos particulares, atravessadouros, e passagens de rios ou ribeiros; acerca do uso das aguas empregadas na agricultura ou mineração; dos pastos, pescas, e caçadas; dos limites, tapagens, e cercados das fazendas e campos; e acerca finalmente dos danos feitos por escravos, familiares, ou animais domésticos.

Pardal exerceu o cargo na freguesia do Engenho Novo quando já tinha se aposentado. Outros professores também exerceram a função ou, ao menos, se candidataram a ela: Simão Bernardino Costa Passos - Juiz de direito do Engenho Velho (Correio Mercantil, 15 maio 1848); Joaquim Sabino Pinto Ribeiro - agradece a indicação para juiz de paz, mas por achar "voto perdido" indica outros três nomes para o cargo (Correio Mercantil, 27 jun. 1856); Joaquim José Cardoso de Siqueira Amazonas - em uma lista para concorrer ao cargo de juiz de paz foi apresentado como médico e professor público (Correio Mercantil, 09 maio 1858); Joaquim José Cardoso de Siqueira Amazonas - anúncio de onde atenderá na função de juiz de paz, que era mesmo endereço da escola (Diário do Rio de Janeiro, 25 jan. 1861), juiz de paz da freguesia de São Cristóvão no período de 1861 a 1864 (AL, 1861); João Ferreira Moscoso - candidato monarquista a juiz de paz (Gazeta da Tarde, 03 ago. 1886); Olympio Catão Viriato Montez - suplente de juiz de paz (Gazeta de Notícias, 18 fev. 1878) e juiz de paz de Paquetá (AL, 1881). A presença de professores primários na função de juiz de paz também foi identificada por Munhoz (2012) na 5 a Comarca de São Paulo, incluindo os postos de júri e vereador, servindo de exemplo para demonstrar que o envolvimento docente em tais atividades também se dava em outras regiões do país.

Flory (1986) ressalta a importância local e informal do juiz de paz. Em sua paróquia "era uma personalidade de carne e osso cujos poderes estavam definidos em igual medida pelas pressões individuais e comunitárias que pelos estatutos e decretos" (p. 109, tradução nossa). ${ }^{2}$ Um professor público primário era uma pessoa de carne e osso conhecida também por sua atuação profissional. Ao ocupar o posto de juiz de paz, poderia mesclar funções diferentes, mas correlatas: educar

2 No original: "era una personalidad de carne y hueso cuyos poderes estaban definidos en igual medida por las presiones individuales y comunitarias que por los estatutos y decretos". 
e ajudar a manter a ordem, encarnando assim duas "missões". O mesmo indivíduo era, pelo menos, ao mesmo tempo, eleitor, juiz e professor público: "como era uma figura tão básica e um produto de seu ambiente, descrever o juiz de paz imperial é, em grande parte, descrever a vida política e social da comunidade paroquial brasileira” (p. 109, tradução nossa). ${ }^{3}$ Dessa forma, no caso das freguesias em que havia a atuação mais intensa dos professores públicos primários, pode-se pensar que descrever o juiz de paz também pode ser descrever a vida política, social e escolar daquele espaço.

O interesse dos professores públicos primários em ocupar o posto de juiz de paz também chama atenção, bem como o fato de exercerem o ensino e o juizado no mesmo lugar, o prédio da escola pública. Era sinal de que a escola, mais do que um espaço de ensinar as primeiras letras, poderia representar um lugar político, concentrando a política de instrução e a política de resolução de problemas locais. De tal forma, a presença de uma escola na localidade poderia gerar mais efeitos do que os esperados pela escolarização primária, dependendo do envolvimento do professor com as agências sociais. Efeitos eleitoreiros, ordenadores, punitivos, conciliadores. Nesse sentido, a importância do papel da escola na paróquia poderia extrapolar as intenções almejadas com o processo de escolarização, visto que poderia estar intensamente envolvida com outros processos políticos e sociais.

O juizado de paz era visto como um instrumento para garantir a "independência judicial" juntamente com outro mecanismo, o de jurado (Flory, 1986). Ser convocado para compor o júri da Corte também tinha relação com as eleições, pois seus membros eram designados a partir do quesito de probidade e do critério de elegibilidade nas eleições de segundo grau. Pardal foi selecionado para o júri várias vezes em sessões em que o promotor público foi seu ex-aluno Antonio Ferreira Vianna - que viria a se tornar inspetor das escolas municipais em 1872 -, que ocupava um posto que participava diretamente da qualificação de jurados.

Além de Pardal, havia uma quantidade significativa de professores convocados para compor o júri da corte: Luis José de Mello (Correio Mercantil, 07 nov. 1848); João José Pereira Sarmento (Diário do Rio de Janeiro, 18 jan. 1834); Felizardo Joaquim da Silva Moraes (Diário do Rio de Janeiro, 18 mar. 1830); João Ferreira Moscoso (Gazeta de Notícias, 07 abr. 1880); Joaquim José de Souza Ribeiro (Gazeta de Notícias, 10 jun. 1888); Antonio Pinto da Costa de Souza Brandão (Correio

3 No original: "como era una figura tan básica y un producto de su ambiente, describir al juez de paz imperial es, en gran parte, describir la vida política y social de la comunidad parroquial brasileña”. 
Mercantil, 21 jul. 1868); José Bernardes Moreira (Diário do Rio de Janeiro, 13 nov. 1873); João da Matta Araujo (Gazeta de Notícias, 05 ago. 1885); Antonio Cypriano de Figueiredo Carvalho (Correio Mercantil, 17 abr. 1858); José Joaquim Xavier (Diário do Rio de Janeiro, 30/05/1871); Gustavo José Alberto (Diário do Rio de Janeiro, 10 jul. 1877); Olympio Catão Viriato Montez (Gazeta de Notícias, 09 ago. 1881); Antonio Candido Rodrigues Carneiro (Gazeta de Notícias, 04 nov. 1885); e João Pedro dos Santos Cruz (Gazeta de Notícias, 08 nov. 1883).

Flory (1986) afirma que as elites se evadiam do dever de jurado porque era um cargo que tomava tempo e porque a presença de pessoas humildes tornava-os mal dispostos a servirem no papel. No entanto, nos conselhos de júri formados e divulgados na imprensa é possível ver a presença de pessoas consideradas de importância, da chamada "boa sociedade".

No Rio de Janeiro, a lei prescrevia seis sessões do júri ao longo do ano. O processo de julgamento possuía várias etapas. Em uma delas, o juiz lia um resumo dos depoimentos e fazia perguntas aos jurados a respeito da existência do delito, da culpabilidade, do grau de culpabilidade e se requeria indenização. Se os jurados declarassem o réu culpado, o juiz de direito ditava a sentença "sendo este virtualmente seu único papel direto em todo o processo" (Flory, 1986, p. 187 , tradução nossa). ${ }^{4}$

A primeira aparição de Pardal como membro do júri, no material pesquisado, ocorre em O Correio da Tarde de 25 de fevereiro 1860, numa lista que incluía também Justiniano José da Rocha no corpo de jurados sorteados para sessão de 14 de fevereiro de 1860; e a última no jornal Brazil - Órgão do Partido Conservador de 03 de dezembro de 1884. Em tais notas, não havia a descrição dos casos a serem julgados. Mas na sessão tratada no Correio Mercantil de 08 de agosto de 1861, em que Pardal estava listado como jurado e o promotor também era Antonio Ferreira Vianna, os tipos de casos apresentados foram de homicídio, furto, estelionato e resistência. Crimes de diversas categorias, acerca dos quais o professor Pardal emitiria mais um tipo de parecer, entre vários que sua profissão lhe outorgava.

Cabe ressaltar que professores também ocuparam outros postos que demandavam contato muito próximo com a população, como de suplente ou subdelegado de polícia. Desse modo, observa-se que a atuação do professor público primário estava comprometida com a escolarização da população, mas

${ }_{4}^{4}$ No original: "siendo éste virtualmente su único papel directo en todo el procedimiento". 
igualmente, por meio de outros tipos de relações oficiais, com ações direcionadas aos habitantes do entorno da escola.

\section{Associações beneficentes e auxiliadoras}

Em 1847, Pardal aparecia na lista dos convidados para serem sócios efetivos da Sociedade Auxiliadora da Indústria Nacional (O Auxiliador da Indústria Nacional, 15 set. 1847), cujo aceite foi registrado no periódico da Sociedade no mês seguinte (27 out. 1847). Ele foi indicado pelo secretário perpétuo da Sociedade, Emilio Joaquim da Silva Maia, que também era professor no Imperial Colégio de D. Pedro II de história natural, geologia e ciências físicas.

Inspirada na Société d'encouragement pour l'Industrie Nationale, a Sociedade Auxiliadora da Indústria Nacional (SAIN), segundo Carvalho (2007) foi criada em 1827 e não se referia à indústria no sentido atual, mas à atividade produtiva em geral que na época era a agrícola. Ressalta que também não se tratava de "um organismo de natureza política, capaz de pressionar o governo em favor de medidas de defesa da indústria, agrícola ou não" (p. 52). Em primeiro lugar, porque recebia dinheiro do governo e, em segundo, porque os secretários-gerais que davam o "tom das posições" da SAIN o faziam em um sentido mais técnico-científico do que político.

Assim, Carvalho assinala que a SAIN era mais próxima de um centro de estudos ou sociedade literária, sendo a participação dos políticos "mais simbólica e honorífica do que instrumental" (p. 52). Ela servia de "fórum no qual os elementos mais progressistas defendiam seus pontos de vista”, como a substituição da mão de obra escrava, clamor que não obteve muito êxito. No entanto, elementos do governo usavam os estudos da sociedade para defender certas reformas. Em vista disso, Carvalho defende que outra instituição, a Associação Comercial, teria tido peso maior na política por tentar influenciar eleiçóes e pressionar o congresso.

A SAIN possuía um periódico, O Auxiliador da Indústria Nacional, publicado a partir de 1833: "uma atividade de difusão do conhecimento científico e tecnológico produzido no interior de uma comunidade específica, a Sociedade Auxiliadora da Indústria Nacional" (Barreto, 2009, p. 270). Cabe assinalar que a SAIN também teve participação na fundação de outras sociedades como a Sociedade de Colonização, em 1835, o Instituto Histórico e Geográfico Brasi- 
leiro, em 1838, e o Instituto Fluminense de Agricultura, em 1860 (Schueler e Gondra, 2008).

Barreto (2009) assinala ainda a iniciativa da SAIN de obtenção de tecnologia. Seu primeiro estatuto oficial registra a disposição de "comprar máquinas, modelos e inventos que pudessem concorrer para o aumento da prosperidade, e manter um 'Deposito e Conservatorio das Machinas, e Modellos', onde os instrumentos adquiridos seriam mantidos em bom estado e asseio" (2009, p. 199). A obtenção de tecnologia também se dava por meio de outras estratégias, como a dos concursos:

A associação funcionaria, portanto, como um órgão consultivo, destinado a promover concursos que estimulassem novos inventores e cientistas a desenvolver máquinas e conhecimentos úteis ao progresso do Império. Para tal função, teria associados qualificados, instruídos em Ciências, que tivessem a capacidade de julgá-los não só pela sua originalidade, mas pela sua funcionalidade (p. 204).

A autora destaca a organização de comissões avaliadoras de acordo com as áreas, das quais fez parte outro professor público primário da Corte, Manoel José Pereira Frazão, que foi, segundo registro do Almanak Laemmert de 1868, membro da "Comissão de comércio e meios de transportes" da SAIN. O Auxiliador registra seu nome como sócio na lista de 1867 (O Auxiliador da Indústria Nacional, 1866). Frazão possuía formação eclesiástica, que abandonou dois anos antes de ser ordenado. Foi estudar na Escola Militar na qual fez o curso de matemática pura, cálculo diferencial e integral e ciências naturais (Blake, 1899). A passagem pela Escola Militar pode ter dado a Frazão uma formação que o permitia participar do trabalho de avaliação requerido pela comissão na SAIN.

Todos os sócios que estivessem devidamente diplomados poderiam assistir a qualquer sessão, propor memórias e escritos que contribuíssem para o melhoramento da indústria ou andamento da sociedade, bem como utilizar a biblioteca, examinar as máquinas, consultar arquivos, atas e registros do Conselho (Barreto, 2009). Tais espaços no interior da SAIN poderiam favorecer o contato de seus membros com as inovações e teorias estrangeiras, propiciando a circulação internacional de ideias. Torna-se importante ressaltar esta possibilidade tendo em vista que neste estudo se pretende também compreender as formas de acesso dos professores públicos primários às teorias pedagógicas estrangeiras no século XIX. 
Iniciativas de caráter pedagógico igualmente faziam parte da SAIN. Em 1848, houve uma reforma dos estatutos, um ano após a entrada de Pardal como sócio efetivo, o que pode ter permitido Pardal participar das discussões que pretendiam alterar o documento. Barreto aponta que os novos estatutos estabeleceram "a institucionalidade da associação como um espaço de caráter educacional” (2009, p. 224). Assim, a Sociedade visava colocar à disposição do público máquinas, biblioteca especializada, coleção de produtos naturais, um periódico e aulas para desenvolver as doutrinas industriais.

Porém, apesar da intencionalidade educativa ter sido institucionalizada na reforma de 1848, Barreto (2009) alerta que discussões sobre a implantação de uma escola normal agrícola iniciaram-se, anteriormente, em 1836:

A Escola funcionaria como um estabelecimento técnico, cujo objetivo central seria o de capacitar jovens e adultos a melhorar a produção agrícola através do conhecimento das novas técnicas, assim como do uso de novas ferramentas e máquinas que dinamizassem esse processo. Funcionaria também como um laboratório, no qual seriam testadas as experiências nacionais e estrangeiras no setor, e máquinas e modelos aprovados ou comprados pela Sociedade (p. 238).

No entanto, somente após 35 anos de discussão, a Escola Normal Agrícola foi inaugurada, em 1871, no mesmo ano da escola noturna para adultos. Na escola noturna podemos observar a presença de outro professor público primário da Corte, João Rodrigues da Fonseca Jordão (O Auxiliador da Indústria Nacional, 1869). O nome foi proposto pelo sócio Joaquim Antonio de Azevedo, conforme registrado em $O$ Auxiliador da Indústria Nacional de 1868. A edição de 1869 relata que o Conselho havia aprovado o funcionamento da escola noturna no mesmo prédio onde estava instalada a escola pública primária da freguesia de Sacramento, em que lecionava Jordão. O professor passaria a receber $600 \$ 000$ pela função. Em 1872, no entanto, Jordão alegou que não poderia exercer o cargo nem se responsabilizar pelos estragos dos móveis da escola pública. Assim, outro professor foi nomeado para o posto e iniciou-se a procura por outro prédio. A questão era que a autorização concedida pelo governo imperial para que a escola noturna funcionasse na escola pública da freguesia de Sacramento estava condicionada à exigência do professor se responsabilizar pela guarda e conservação dos móveis e utensílios. Risco que Jordão talvez tenha decidido não correr, diante do baixo salário que recebia como professor público. 
Segundo Barreto, a escola noturna deveria "preparar os alunos para cursarem a Escola Industrial, onde seriam aplicados os estudos técnico-profissionalizantes concernentes aos 'diversos ramos da indústria artística e manufactureira'." (p. 245-246, aspas da autora). A Escola Industrial foi inaugurada em 1872 e, na lista de seus professores, podemos identificar outro professor público primário, Antonio Estevão Costa e Cunha, responsável por ensinar gramática, filologia e composição portuguesa (AL, 1875).

Também fizeram parte da SAIN outros sujeitos que possuíam conexões com os professores primários em geral, como o político liberal Adolpho Bezerra de Menezes; o inspetor da instrução Eusébio de Queiroz; vários delegados da instrução, como, por exemplo, José Agostinho Moreira Guimarães (freguesia de Santa Rita), Roberto Jorge Haddock Lobo (Engenho Velho), Manoel Pacheco da Silva (Santana/Santo Antônio) e Lopo Diniz Cordeiro (São José/Candelária); bem como pais ou encarregados de alunos de Pardal, como o Visconde de Baependy e Theodoro Jansen Muller e o ex-aluno José Antonio Ferreira Leal.

Outra sociedade auxiliadora da qual os professores fizeram parte, mas de caráter distinto da SAIN, foi a Imperial Sociedade Auxiliadora das Artes Mecânicas e Liberais e Beneficente. O professor José Alves da Visitação foi suplente de secretário (AL, 1874), secretário (Gazeta de notícias, 14 fev. 1882) e vice-presidente (AL, 1884); José Bernardes Moreira foi vice-presidente (AL, 1864), presidente (AL, 1866) e secretário da administração da caixa do estabelecimento Pio da sociedade (AL, 1870); e Augusto Candido Xavier Cony foi conselheiro (Diário do Rio de Janeiro, 13 mar. 1877).

Segundo o Dicionário do Movimento Operário (Batalha, 2009), a sociedade foi fundada em 1835, com estatutos aprovados em 1837, e tinha como objetivo a beneficência e o melhoramento e progresso das artes. Em torno de 1877, divergências durante a reforma do estatuto alteraram sua composição original e a sociedade passou a aceitar comerciantes, capitalistas e "negreiros". No entanto, conforme já indicado, antes da reforma, já faziam parte dela pelo menos três professores primários que ocupavam cargos diretivos.

A Sociedade Propagadora das Belas Artes constitui outra instituição na qual observamos professores públicos primários. João Rodrigues da Fonseca Jordão foi suplente da comissão econômica (AL, 1858) no período em que atuava na escola pública da freguesia da Lagoa. Segundo o estatuto de 1862, a finalidade da sociedade era promover "a propagação, desenvolvimento e perfeição das artes em todo o Império", bem como "elevar os artistas, fazendo nascer 
em todas as classes do povo o gosto pelo belo, necessário não só como meio de educação, mas também como acessório essencial a todos os ofícios e indústrias manufatureiras". Para atingir tais fins, a sociedade pretendia, de acordo com seus recursos: fundar um liceu de artes e ofícios, publicar uma revista artística, criar uma biblioteca, realizar sessões públicas para leitura de escritos sobre as artes e indústrias e exposição dos trabalhos dos alunos do liceu, com concessão de prêmios por meio de concursos públicos e de viagem aos mais distintos alunos do liceu à Europa, correspondência com as sociedades nacionais e estrangeiras de igual fim e cooperação para o estabelecimento de outras sociedades semelhantes nas demais províncias do Império.

Segundo Gondra e Schueler (2008), a Sociedade foi responsável pela criação do Liceu de Artes e Ofícios da Corte, que começou suas atividades em 1858, instituição na qual estudou Augusto Candido Xavier Cony (Correio Mercantil, 19 mar. 1858) e na qual foi lecionar um ex-aluno de Pardal, conforme assinalado no capítulo II.

O movimento de criação desses liceus por sociedades beneficentes, na segunda metade do século XIX, segundo Castanho (2007), ocorreu em diversas províncias do país. Desse modo, vale ressaltar que outros professores públicos, como José João de Póvoas Pinheiro e Antonio José Marques, fizeram parte da Associação Protetora do Liceu Artístico Industrial. O primeiro, como membro do conselho (Diário de Notícias, 26 ago. 1883) e o segundo, inicialmente, como secretário. Em 1884, o professor Marques aparece como presidente do referido Liceu (AL, 1884).

Em estudo sobre as escolas noturnas, Costa (2007, p. 49) afirma que o Liceu "seria um espaço de formação de mão-de-obra para indústria nascente e para os demais setores da vida urbana, mas não simplesmente pelo inculcamento de saberes técnicos". A autora assinala que

Esta instituição funcionava em prédios das escolas públicas da freguesia de Santa Rita concedidos pelo governo imperial ao seu iniciador, professor Antônio José Marques. Seu programa de estudos era dividido entre "matérias preparatórias" e além destas, em mais três cursos diferentes: o artístico, o comercial e o industrial (p. 113, aspas da autora).

Antonio José Marques havia lecionado nas escolas públicas da freguesia da Candelária (1871-1875) e da Lagoa (1875-1880), sendo removido para $1^{\text {a }}$ 
Escola Pública da freguesia de Santa Rita em 1880, anos antes da fundação do Liceu e de assumir a presidência da Associação. Apesar da atuação mais intensa na década de 1880, segundo documento localizado por Costa (2007), o professor Marques havia tentado abrir um curso noturno quando atuava na escola pública da Lagoa, mas não obteve autorização do governo para abertura oficial. No entanto, o professor conseguiu fazer funcionar a aula como "ensaio", sem receber remuneração pelo serviço. Talvez configurasse uma estratégia para provar, por meio da procura e da quantidade de alunos que frequentavam o "ensaio", a necessidade da classe na localidade.

A atuação desses professores mostra que estavam engajados com as questões concernentes ao desenvolvimento industrial e tecnológico do país e à formação de trabalhadores. Não obstante, Costa (2007) assinala que a prioridade de tais escolas não consistia apenas em ensinar os saberes primários, "mas ensiná-los para usos determinados”, como forma de controle social, contrastando com as iniciativas educativas promovidas no interior das próprias classes trabalhadoras. Nesse sentido, a atuação de Póvoas Pinheiro nos dois lados, no da ação de grupos das elites e no das classes trabalhadoras, chama atenção. Ao mesmo tempo em que estava empenhado no funcionamento de um Liceu pertencente à Sociedade Propagadora das Belas Artes, também estava atuando no interior de uma instituição organizada pela classe trabalhadora, como secretário da Associação Operária Emancipadora Vicente de Souza (AL, 1885). O fato denota a complexidade das relações e inserções em diferentes tipos de grupos sociais.

Uma forma diferente de envolvimento institucional tem a ver com o outro tipo de formação e, possivelmente, de ocupação, dos professores Antonio Joaquim Teixeira de Azevedo (AL, 1874) e Antonio Estevão da Costa e Cunha (AL, 1875). Ambos foram membros do Instituto Farmacêutico do Rio de Janeiro. O Instituto foi criado em 1858, mesma década em que foi fundada outra sociedade da área (Sociedade Farmacêutica Brasileira) e, de acordo com Edler (2006), ambos visavam regulamentar o exercício do oficio, por meio da melhoria do ensino, do combate ao exercício ilegal e da elaboração de um código farmacêutico para padronizar a preparação e uso de medicamentos. Em 1874, segundo Edler, o Instituto criou uma escola preparatória (Escola de Humanidades e Ciências Farmacêuticas) para ingresso no curso de Farmácia na Faculdade de Medicina. Tanto Azevedo quanto Costa e Cunha fizeram parte do corpo docente do curso de ciências farmacêuticas da escola preparatória (A Escola, 1877, p. 77-78). 
A presença de tantos professores primários da Corte no ensino de adultos, no ensino profissional e, até mesmo, atuando em sociedades de trabalhadores, denota que professores primários exerciam uma agência junto às classes trabalhadoras ensinando as primeiras letras, mas também participando da formação profissional e da organização de associações de trabalhadores. Igualmente se insere, nesse caso, a participação de professores em sociedades abolicionistas, em que pese o fato de que vários foram proprietários de escravos ao longo de suas vidas como Frazão, José Bernardes Moreira, Polucena Maria da Conceição Cruz (Correio Oficial, 23 maio 1836) e Pardal.

\section{Socorros mútuos, previdência, seguro}

Os professores igualmente recorriam a instituições de socorros mútuos, previdência, caixas econômicas, entre outras, como meio de garantir alguma assistência em situações mais complicadas. Havia aquelas fundadas e direcionadas à classe docente, mas vários professores também eram membros de outras instituições que não tinham caráter corporativista.

Quadro 24 - Instituições de socorro mútuos e similares

\begin{tabular}{|c|l|l|}
\hline N. & Professor & Condição \\
\hline 1 & $\begin{array}{l}\text { Felizardo Joaquim da } \\
\text { Silva Moraes }\end{array}$ & $\begin{array}{l}\text { Contribuía para o Montepio Geral de Economia dos Servidores do } \\
\text { Estado (Diário do Rio de Janeiro, 22 set. 1835). }\end{array}$ \\
\hline 2 & $\begin{array}{l}\text { Francisco Joaquim } \\
\text { Nogueira Neves }\end{array}$ & $\begin{array}{l}\text { Contribuía para o Montepio Geral de Economia dos Servidores do } \\
\text { Estado (Correio Oficial, 11 jan. 1836). }\end{array}$ \\
\hline 3 & $\begin{array}{l}\text { Francisco Antonio } \\
\text { Augusto de Sá }\end{array}$ & Instituidor de Montepio Geral (AL, 1852). \\
\hline 4 & $\begin{array}{l}\text { Joaquim Sabino Pinto } \\
\text { Ribeiro }\end{array}$ & Instituidor de Montepio Geral (AL, 1852). \\
\hline 5 & $\begin{array}{l}\text { Francisco Alves da Silva } \\
\text { Castilho }\end{array}$ & $\begin{array}{l}\text { Membro da associação de benefícios mútuo para criação de capitais e } \\
\text { renda (Diário do Rio de Janeiro, 14 ago. 1873). }\end{array}$ \\
\hline 6 & José Bernardes Moreira & $\begin{array}{l}\text { Secretário da Sociedade Brasileira de Beneficência (AL, 1860) e conse- } \\
\text { lheiro (AL, 1862). }\end{array}$ \\
\hline 7 & $\begin{array}{l}\text { João Marciano de } \\
\text { Carvalho }\end{array}$ & $\begin{array}{l}\text { Contribuinte da associação brasileira de seguro mútuo sobre a vida (A } \\
\text { Nação, 31 maio 1873). }\end{array}$ \\
\hline 8 & João da Matta Araujo & $\begin{array}{l}\text { Secretario da Associação Baiana de beneficência (Gazeta de Notícias, } \\
29 \text { jun. 1888); contribuía para o montepio dos funcionários públicos } \\
\text { conforme assinala viúva (O Paiz, 29 set. 1896). }\end{array}$ \\
\hline
\end{tabular}




\begin{tabular}{|c|l|l|}
\hline 9 & $\begin{array}{l}\text { Joaquim Antonio da } \\
\text { Silva Bastos }\end{array}$ & $\begin{array}{l}\text { Membro da associação de benefícios mútuo para criação de capitais e } \\
\text { renda (Diário do Rio de Janeiro, 14 ago. 1873). }\end{array}$ \\
\hline 10 & $\begin{array}{l}\text { Manoel José Pereira } \\
\text { Frazão }\end{array}$ & $\begin{array}{l}\text { Membro do Conselho Fiscal da Sociedade de socorros à invalidez (AL, } \\
1878) .\end{array}$ \\
\hline 11 & Gustavo José Alberto & $\begin{array}{l}\text { Associado da Associação de benefícios mútuos e Caixa econômica } \\
\text { auxiliar perseverança brasileira (O Globo, 01 jan. 1875); membro da } \\
\text { diretoria da Associação Baiana de beneficência (Diário do Brasil, 19 jun. } \\
1883) .\end{array}$ \\
\hline 12 & $\begin{array}{l}\text { Antonio Candido } \\
\text { Rodrigues Carneiro }\end{array}$ & $\begin{array}{l}\text { Conselheiro da Imperial Sociedade União beneficente 29 de julho } \\
\text { (Gazeta de Notícias, 1880). }\end{array}$ \\
\hline 13 & $\begin{array}{l}\text { João Pedro dos Santos } \\
\text { Cruz }\end{array}$ & $\begin{array}{l}\text { Membro da diretoria da Caixa escolar Beneficente da Lagoa (Gazeta de } \\
\text { Notícias, 28 out. 1884). }\end{array}$ \\
\hline 14 & $\begin{array}{l}\text { José João de Povoas } \\
\text { Pinheiro }\end{array}$ & $\begin{array}{l}\text { Associado da Associação de benefícios mútuos e Caixa econômica } \\
\text { Congresso beneficente Martins de Pinho (Diário de Notícias, 16 ago. } \\
1886) ; \text { Conselheiro da Associação beneficente de seguro de vida "A } \\
\text { humanitária" (O Paiz, 03 dez. 1896). }\end{array}$ \\
\hline
\end{tabular}

Fonte: Quadro elaborado pela autora com base nas informações levantadas nos jornais da Hemeroteca Digital da Biblioteca Nacional e no Almanak Laemmert.

Pardal participou do conselho de administração, como secretário e conselheiro, de uma associação de seguro bastante diferente: "Imperial Companhia de Seguro Mútuo Contra Fogo". Segundo o estatuto de 1877, a companhia foi fundada em 1854, com objetivo "principal e único garantir mutuamente aos seus associados, quaisquer riscos e danos, provenientes de incêndios, causados às propriedades que na mesma estiverem seguras." No entanto, ficavam excluídos do seguro de prédios "os teatros públicos ou particulares, os circos ou praças, a Alfândega, a estiva, o Consulado e os trapiches com as mercadorias aí depositadas”. Segundo Saes e Gambi (2009, p. 2), “a expansão dessa atividade esteve intimamente associada às crescentes necessidades impostas a uma sociedade em transformação". Para os autores, a formação e a consolidação do setor no Brasil ocorreu ao longo do século XIX:

Apesar de algumas semelhanças com a pioneira experiência inglesa, por exemplo, a origem do setor com os seguros marítimos e a subsequente formação das Companhias de Seguros de Vida e "Contra Fogo", a história das Companhias de Seguros no Brasil apresenta características próprias: país escravista e periférico, sem passar por um processo de industrialização durante o século XIX, e cuja 
interferência estrangeira foi determinante na constituição do capitalismo local (p. 5, aspas dos autores).

Os autores destacam que somente em 1850 o governo aprovou um Código Comercial que viria favorecer as companhias de seguros, juntamente com a extinção do tráfico de escravos e a Lei de terras. Havia dois tipos de companhias de seguro, as sociedades anônimas e as mútuas. As primeiras eram sociedades com grande investimento de capital e constituíam a maioria das empresas, e as segundas "eram empresas em que todos os sócios dispunham, como proprietários, do mesmo tipo de objeto segurado: fossem embarcações, escravos, prédios ou outras mercadorias" (p. 15). Dessa forma, chama atenção outra companhia de seguro da qual Pardal fez parte, a Companhia Mútua de Seguro de Vida de Escravos. De acordo com Saes e Gambi (2009), o seguro de escravos transportados por navios não era permitido pelo Código Comercial Brasileiro, em razão da proibição do tráfico negreiro, mas como o escravo tinha alto valor nas fazendas e propriedades urbanas, "seu seguro tornou-se uma peculiaridade do mercado nacional, enquanto a escravidão já havia sido abolida em quase todo o mundo" (Saes e Gambi, 2009, p.16).

Os professores João Marciano de Carvalho e José João de Povoas Pinheiro também eram ligados a instituições de seguro de vida. Segundo Saes e Gambi (2009, p. 15), "tal modalidade foi pouco propagada pelo receio de que pudesse incentivar mortes encomendadas". Povoas Pinheiro e Gustavo José Alberto eram membros da Associação de Benefícios Mútuos e Caixa Econômica Auxiliar Perseverança Brasileira ( $O$ Globo, 01 jan. 1875). Apesar do nome, também era de seguro de vida. O estatuto de 1874 a define como uma sociedade anônima, portanto tratava-se de uma grande empresa. Seu primeiro artigo definia que "sob a denominação de Perseverança Brasileira estabelece-se no Rio de Janeiro uma Associação mútua de seguros sobre vidas e Caixa Econômica de depósitos parciais" (Decreto n. ${ }^{\circ}$ 5.767, 14 out. 1874). A diferença entre as duas finalidades fica explicitada no quinto artigo:

Art. $5^{\circ}$ Os fins a que se propõe a Associação são:

$1^{\circ}$ Nas operações de seguro sobre vida: Facilitar a todas as pessoas de diferentes classes da sociedade, ainda mesmo as menos favorecidas da fortuna, a acumulação parcial de suas economias para criação de capitais e benefícios futuros, por meio de prestações feitas por ano, semestre, trimestre ou de uma só vez. 
$2^{\circ}$ Nas operações da Caixa Econômica: Receber em depósito qualquer quantia de um mil réis para cima em conta corrente ou a prazo fixo, conforme a sua tabela, com o fim especial de facilitar à classe pobre e previdente a inscrição do seguro sobre vida.

O artigo chama atenção por evidenciar que as pessoas "menos favorecidas da fortuna" ou a "classe pobre" poderiam fazer parte da instituição, por meio de estratégias que visavam favorecer sua inscrição na sociedade, via "operações da Caixa Econômica”. A lista em que constavam os nomes dos dois professores também se destaca por outro aspecto: a presença significativa de mulheres associadas. Se eram elas mesmas que requeriam inscrição ou se eram seus parentes, não foi possível saber pelos limites da pesquisa, bem como as pretensões. Contudo, a preocupação em fazer seguro de vida para a mulher existia, aspecto interessante para compreender a posição feminina no que diz respeito a práticas econômicas e de seguro.

No caso dos montepios, entre os professores pesquisados cinco tiveram inscrição em tais instituições. O Montepio Geral de Economia dos Servidores do Estado, de caráter previdenciário, contou com pelo menos três professores. Foi criado, em 1835, pelo Ministro Aureliano de Souza e Oliveira Coutinho, com o intuito de beneficiar "sem gravame do Tesouro Público Nacional, as famílias dos empregados públicos, que falecerem sem lhes deixar meios de honesta subsistência" (Decreto de 10 jan. 1835). O Montepio Geral dos Servidores é considerado por pesquisadores da área previdenciária (Martinez, 2007) como "marco" do nascimento da previdência privada no Brasil, sendo uma instituição que continua em funcionamento até os dias atuais. ${ }^{5}$

Gustavo José Alberto e João da Matta Araújo eram da diretoria da Sociedade Bahiana de Beneficência. Essa associação se insere nos moldes de socorros mútuos, embora não traga no título a expressão. Sua criação se deu em 1881 e seu estatuto definia que sua finalidade era socorrer os sócios, nos casos de moléstia, invalidez e prisão; fazer-lhes o funeral; estabelecer uma pensão por morte a suas famílias; protegê-los em qualquer ocasião fora dos casos acima especificados. Havia dois tipos de sócios. Os efetivos eram "os filhos da Província da Bahia que se acharem no perfeito gozo de saúde quando propostos, forem de bons costumes e tenham meio de vida honesta" e os honorários aqueles "de qualquer

${ }^{5}$ Cf. Mongeral Aegon. Disponível em: https://www.mongeralaegon.com.br/mongeral-aegon/sala-de-imprensa/releases/detalhe-de-releases-20.htm. Acesso em maio de 2014. 
nacionalidade que prestarem serviços importantes à associação ou protegerem os sócios efetivos" (Decreto n. ${ }^{\circ}$ 8.007, 26 fev. 1881).

O investimento de professores em seguros de escravos, de vida e contra fogo, sugere que possuíam algo que consideravam de valor e que temiam perder, por isso, os seguros possibilitariam uma forma de compensar para eles ou para as famílias perdas e danos de bens. Quanto à subsistência, as sociedades de socorros mútuos e os montepios eram instituições que poderiam conferir auxílio em situações difíceis. A inscrição dos professores em tais instituições pode ter a ver com o fato de não receberem salários condizentes com as suas necessidades e de não haver pensão levando-os a temer as condições em que deixariam suas famílias, após sua morte.

\section{Irmandades e ritos religiosos}

Pardal ocupou cargos na administração de três irmandades/devoção: escrivão e secretário da Irmandade do Apóstolo Evangelista São Matheus; protetor da Devoção da Nossa Senhora da Madre de Deus; e definidor da Irmandade Nossa Senhora da Luz. Nos casos da Irmandade de São Matheus e da Devoção, a atuação de Pardal foi marcada pela autoria e publicação de notas com diversos fins nos jornais.

Enquanto protetor da "Devoção", em 1860, Pardal convocava os devotos a mandarem suas esmolas para o endereço da botica no Largo da Imperatriz, n. 121 (Correio Mercantil, 04 out. 1860). O anúncio coloca "botica” entre parênteses, para dar destaque, pois como já mencionado, esse endereço era o mesmo da Escola Pública de Santa Rita.

O processo de formação de um grupo de "devoção" tinha uma trajetória simples, segundo Cavalcanti (2004). Bastava atingir certo nível de organização, registrar direitos e deveres em um "compromisso", espécie de estatuto que definia regras disciplinas sem necessidade de oficialização formal: "Poderiam estruturar-se em torno de um oratório de rua, de casa particular, de altar de uma igreja com a permissão da Irmandade proprietária ou de seu pároco” (p. 206). A organização simples permite compreender o local combinado para entrega de esmolas dos devotos, a botica. Lugar conveniente para o "protetor" Pardal, pois era próximo do professor e não atrapalhava as aulas na escola.

Enquanto escrivão e secretário da Irmandade de São Matheus, Pardal colocava anúncios nos jornais de grande circulação, Diário do Rio de Janeiro e 
O Mercantil, para divulgar festas em homenagem ao apóstolo, no período entre 1845 e 1850. Nos anúncios se informava que São Matheus estava "ereto" ou se "venera" na Igreja de Nossa Senhora de Lampadosa, local onde era realizada a festa. Tal igreja, localizada na freguesia de Sacramento, aparece na historiografia como um espaço frequentado por negros. Lopes assinala que a Igreja, na primeira metade do século XIX, pertencia a uma irmandade de mulatos, servida por clero negro e abrigava um "cemitério dos africanos abastados" (Lopes, 2006).

Figura 29 - "Enterro de uma mulher negra" de Jean-Baptiste Debret

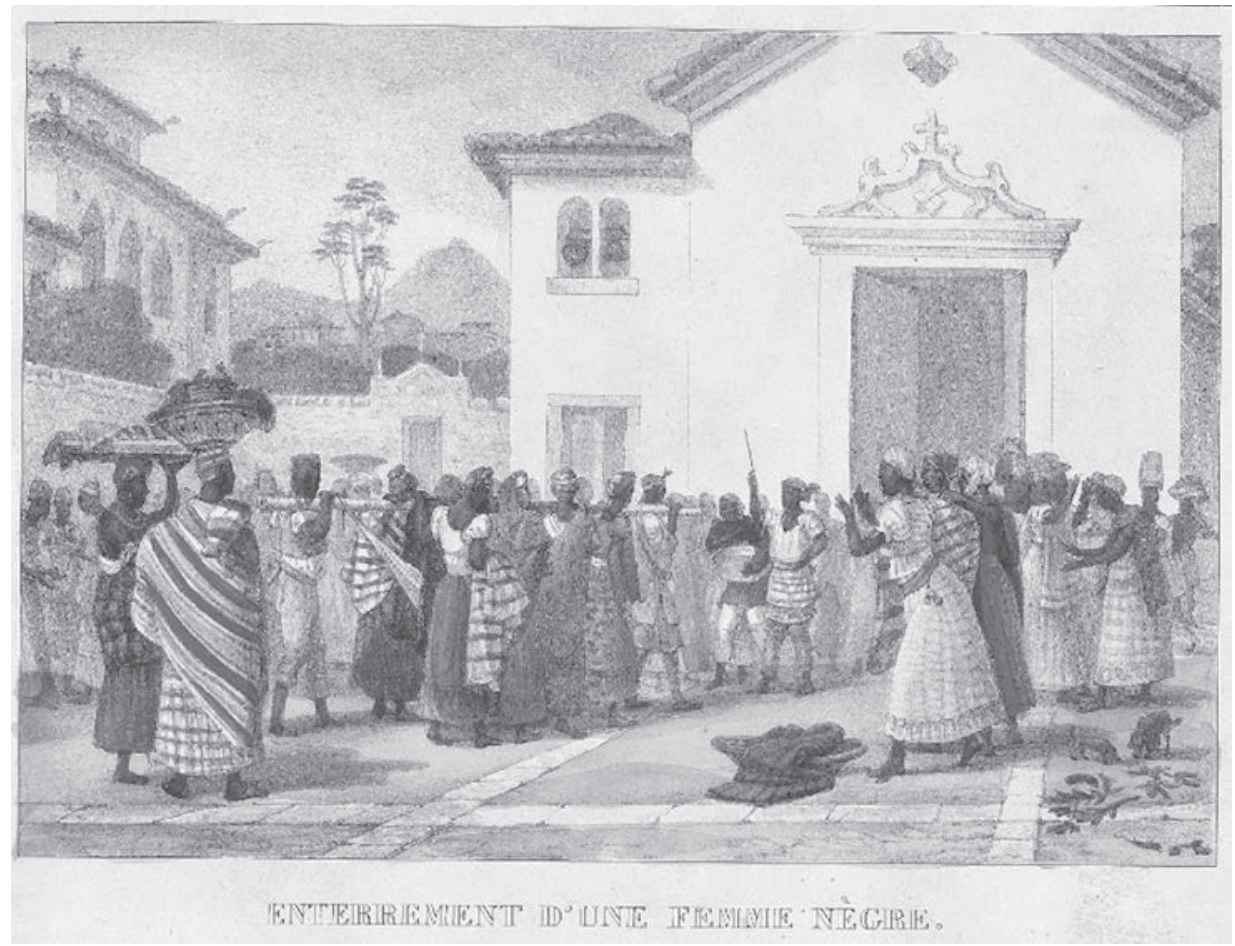

Fonte: Biblioteca Nacional.

Uma pintura de Jean-Baptiste Debret, chamada "Enterro de uma mulher negra”, tem como fundo a Igreja (Leenhardt, 2006). A cena, de acordo com Leenhardt, retrata um espaço com forte conotação simbólica:

[...] a igreja aqui representada, Nossa Senhora da Lampadosa, com seus signos religiosos inscritos no pórtico principal e os sinos em uma espécie de campaná- 
rio erguido sobre um dos lados; a casa do senhor, um sobrado imponente, cujas janelas talhadas em ogivas góticas reforçam o clima eclesiástico para além do seu uso familiar (p. 123).

A imagem, segundo Leenhardt, é tratada como um documento no estudo dos rituais da vida da população africana no Brasil. Por meio da pintura, ele ressalta, por exemplo, o fato das mulheres africanas estarem familiarizadas com a experiência religiosa católica, por serem obrigadas a seguir com suas patroas os rituais da religião. Tal análise é feita em contraposição à pintura "O enterro do filho de um rei negro", também de Debret, em que a cena não denota a mesma perspectiva de ordem da pintura "Enterro de uma mulher negra" (Leenhardt, 2006).

Outra informação a respeito dos frequentadores da Igreja aproxima, novamente, Pardal de um personagem já mencionado. Facioli (2008) afirma que a madrasta de Machado de Assis, após a morte do pai dele em 1851, passou a fabricar e vender doces como meio de sustento. Para ajudar, Machado se tornou auxiliar do sacristão da Igreja de Nossa Senhora de Lampadosa, que Facioli ressalta ser uma das mais importantes irmandades de escravizados, libertos e negros livres. Os caminhos na cidade de Pardal e Machado de Assis mais uma vez se cruzavam.

As características da sociedade brasileira nos Oitocentos tornam bastante complexa a análise das relações travadas no período, como o modo que Pardal lidou com a questão da escravidão e do abolicionismo. Era membro da diretoria de uma irmandade ereta numa igreja de negros, num momento em que ele possuía escravizado, pois foi nessa época, mais precisamente no final do ano de 1848, que seu escravizado, João Congo, atentou contra sua vida, sendo preso por isto (Correio Mercantil, 31 dez. 1848). Foi membro de uma associação de seguro de escravos e, posteriormente, de uma sociedade abolicionista. Tais fatos ocorreram em fases diferentes de sua vida. O incidente com João Congo se deu quando Pardal tinha 30 anos de idade e a participação na sociedade abolicionista se deu aos 65 anos. Ao transitar por posições distintas, torna complexa a compreensão dos processos e das maneiras do professor se posicionar e agir quanto ao assunto, ao longo do tempo.

Outros professores também compunham a mesa diretora de irmandades, como Francisco Antonio Augusto de Sá, mesário da Irmandade Santo Antônio dos Pobres e Nossa Senhora dos Prazeres (AL, 1861); José Theodoro Burlamaque, tesoureiro (AL, 1873) e definidor da Irmandade Nossa Senhora da Apresentação do SS. Sacramento da freguesia de Irajá (AL, 1876); Antonio Ignácio Mesquita, devoto da Irmandade do Senhor do Bonfim (Diário do Rio de Janeiro, 27 out. 1868); 
e José Bernardes Moreira que constava na lista de irmãos e devotos da Irmandade de Nosso Senhor do Bonfim que contribuíram para o translado da imagem do Nosso Senhor do Bonfim para Igreja de Santo Inácio (Correio Mercantil, 11 dez. 1857), era irmão de capela da Irmandade do Nosso Senhor Santo Cristo dos milagres (Diário de Notícias, 21 jun. 1871), secretário da Irmandade do Divino Espírito Santo da freguesia de Santa Rita (AL, 1885) e juiz jubilado da Irmandade do Glorioso Mártir São Braz (Gazeta de Notícias, 08 fev. 1881).

A atuação ligada à religião poderia se dar de outras formas, como a de Francisco Joaquim Nogueira Neves, que foi padrinho de um "chim" convertido (Diário do Rio de Janeiro, 11 maio 1856). Pardal também foi padrinho de casamento do seu ex-adjunto e professor primário Antonio Ignacio de Mesquita Júnior (Correio Mercantil, 27 abr. 1857). Jose Joaquim Pereira de Azurara foi testemunha de casamento evangélico (A Imprensa Evangélica, 19 dez. 1874). Acerca do caso de Azurara, não foi possível saber se havia sido convidado para ser padrinho por relações de amizade ou parentesco, se o professor frequentava algum espaço de caráter protestante ou se havia se convertido ao protestantismo. Cabe destacar que no período de 1850 a 1900, ocorreu o chamado "protestantismo de missão", no qual a vinda de protestantes se revestia de um caráter missionário, proselitista, em contraposição à primeira metade do século, em que no chamado "protestantismo de capela" os imigrantes viviam sua religião, mas não faziam proselitismo de sua igreja e escola (Hilsdorf, 1977).

O dito casamento foi celebrado pelo Reverendo Alexander Lastimer Blackford. Americano, Blackford era pastor missionário da Igreja Evangélica Presbiteriana, na Travessa da Barreira. A Igreja foi fundada em 1862 pelo pastor A. G. Simonton, que havia chegado ao Brasil em 1859, e estava ligada à ação missionária da Igreja Presbiteriana do Norte dos Estados Unidos, que, numa linha de análise que desconsidera o trabalho de Robert Kalley como pastor e missionário, teria sido a primeira a retomar os trabalhos no Brasil de forma permanente. Em 1864, Simonton fundou o jornal A Imprensa Evangélica (Hilsdorf, 1977), periódico em que foi divulgado o casamento do qual Azurara foi padrinho.

\section{Atividades recreativas}

Pardal foi membro de diversas sociedades recreativas e musicais, como a Sociedade de Baile Guanabara, Sociedade Campestre, Club Fluminense, Club Mozart e Sociedade Recreio Dramático Riachuelense. Segundo Silva (2007), 
várias entidades promotoras de concertos foram criadas na segunda metade do século XIX, como o Club Mozart que teve importante atuação no cenário musical carioca. Apoiada nas pesquisas de Cristina Magaldi, Silva (2007, p. 22) assinala que

[...] os clubes de música também fazem parte do processo de modernização urbano da cidade que teve entre suas principais influências a Inglaterra e França. Os clubes de música propiciaram também um ar cosmopolita para a vida musical na corte tornando-se importantes agentes na promoção de concertos na cidade.

No Club Mozart, Pardal foi secretário (Correio do Brazil, 28 dez. 1872). Era uma instituição recreativa, fundada em 1867 , voltada para o desenvolvimento da música vocal e instrumental. Magaldi (2004) coloca o clube como um espaço frequentado pela elite, que também contou como membro, ocupando o cargo de tesoureiro da instituição, outro professor primário (AL, 1884), Gustavo José Alberto, baiano e negro, segundo Schueler (2008a). Nesse sentido, Silva também destaca o fato de Machado de Assis ter trabalhado como bibliotecário do Club Beethoven por representar a inserção de uma parcela da população em instituições entendidas como elitistas: “apesar do caráter segmentário, essas instituições recreativas possibilitavam uma convivência de diferentes socialmente, mas que estavam ligados em torno de um tipo de divertimento" (p. 24).

Cabe atentar para o fato de que o Club Mozart também teve sua parcela de contribuição na organização da categoria, pois seu espaço seria usado para reunião de professores em 1884 (Gazeta da Tarde, 26 abr. 1884). A convocatória era seguida de uma numerosa lista de professores, entre os quais quatro mulheres. O professor Gustavo, que era tesoureiro do Club nesse período, não consta na lista, mas pode ter facilitado a autorização para a realização do evento. Tal fato denota o trânsito, a agência e o intercâmbio existentes entre os espaços, sujeitos e atividades que, a princípio, não eram correlatos, mas acabavam se conectando por conta dos sujeitos que os colocavam em funcionamento. As atividades musicais poderiam ser exercidas por professores de maneira autônoma como no caso de Antonio Ignácio de Mesquita Júnior que apresentou no Teatro São Pedro de Alcântara uma sinfonia composta para João Caetano (Diário do Rio de Janeiro, 22 set. 1860). O professor também compôs uma música para o funeral do ex-inspetor Eusébio de Queiroz, em 1868 (Correio Mercantil, 09 jul. 1868). 
Figura 30 - Nota de convocatória dos professores

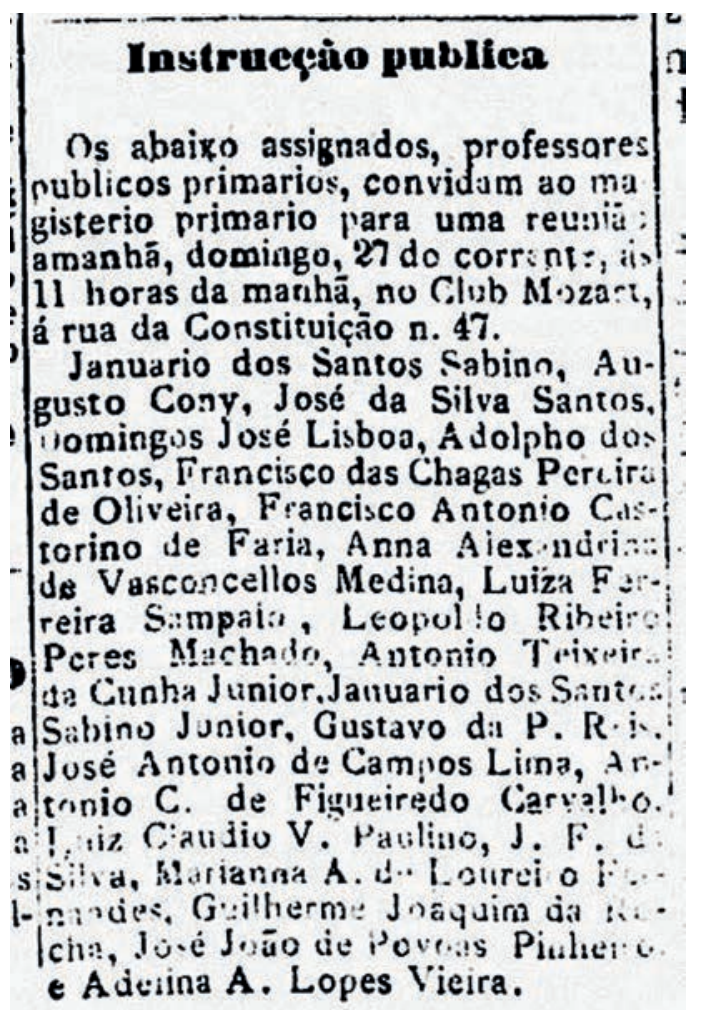

Fonte: Gazeta da Tarde, 26 abr. 1884, Biblioteca Nacional.

Outra instituição administrada por Pardal, enquanto secretário, foi a Sociedade Campestre. Ele também contou com um colega docente como parte da equipe diretiva no mesmo período, o professor da Escola Pública da freguesia da Candelária, Luiz Thomaz de Oliveira, na condição de procurador (Correio Mercantil, 15 abr. 1860). A parceria com colegas também se deu em outra instituição, a Sociedade Particular Recreio Dramático Riachuelense. Segundo o estatuto de 1877, tinha "por fim promover entre seus associados o recreio e instrução por meio de representações de dramas, tragédias, comedias, etc.”. A sociedade era proprietária de um terreno registrado no próprio estatuto:

Art. $7^{\circ}$ Constituem fundo da Sociedade: vinte e dois metros de terreno à rua D. Anna Nery na Estação do Riachuelo e o teatro que se está edificando no mesmo terreno, tudo no valor de vinte contos de réis, representado por duzentas ações de cem mil réis cada uma. 
Coincidentemente ou não, o terreno ficava na mesma rua em que Pardal foi residir na freguesia do Engenho Novo, provavelmente em 1874, ano em que foi exonerado do cargo de subdelegado por motivo de mudança (Diário do Rio de Janeiro, 05 set. 1874). A proximidade geográfica entre residência e sociedade facilitava a presença do professor nos vários cargos que ocupou na diretoria da sociedade.

De acordo com o estatuto de 1877 , a administração da sociedade era composta por uma diretoria de sete membros e de um conselho de dez, todos acionistas. A diretoria era formada pelo presidente, vice-presidente, diretor de cena, 1. Secretário, 2. Secretário, tesoureiro e procurador. O professor Pardal ocupou vários cargos. Fez parte do conselho, foi secretário, vice-presidente e presidente. No mesmo período em que era vice-presidente, o professor Augusto Candido Xavier Cony - que nesse momento também se tornava eleitor na freguesia de Santana pelo Partido Liberal -, assumia a comissão de contas da entidade (O Cruzeiro, 13 jun. 1878).

A família de ambos os professores esteve envolvida em diversas atividades teatrais da Sociedade Riachuelense. A segunda esposa de Pardal, Elysa, participou de várias encenações e recebeu diversos elogios nos jornais por seu talento. A primeira menção localizada foi em um artigo intitulado "Palcos, salões e circos" no jornal Gazeta da Noite (21 jan. 1880). O artigo destaca o brilhantismo da apresentação do drama "Os íntimos", de Victorien Sardou, na Sociedade Riachuelense e faz a ressalva de que

Não costumamos trazer para estas colunas os nomes dos que, amando a arte, fazem, quase que em família, as oblações aquela imortal Deusa, já porque não é estilo, já porque não devemos ofender as modéstias de quem tão modestamente se oculta. Porém, hoje tomamos a responsabilidade grave de darmos os nomes daqueles que, nos entusiasmando tanto, obrigando-nos a lhes ofender a modéstia dizendo que: A Exma Sra. D. Elysa Pardal no papel de Cecília revelou mais uma vez seus altos talentos e principalmente no terceiro ato quando, com Maurício, luta para deixar sua honra ilesa. Toda a ação, toda a vida, todo o jogo necessários àquela cena foram perfeitamente compreendidos pela Sra. D. Elysa.

A personagem Cecília mesclada à atuação de Elysa foi assunto de outro artigo em edição posterior do jornal. Apesar dos elogios, Elysa fazia parte de um grupo considerado amador, como pode ser visto nas observações dos jornais. A esposa de Pardal atuou em atividades de outras instituições, como, por exemplo, ao recitar uma poesia na 
cerimônia de posse da nova administração da Irmandade do Santíssimo Sacramento da Candelária (A Folha Nova, 02 ago. 1883).

Também fazia teatro amador o filho do professor Augusto Candido Xavier Cony, de mesmo nome. Cony Júnior estudou na Escola Pública de Santana, onde o pai lecionava e onde ganhou uma medalha prateada, nos prêmios distribuídos aos alunos no ano de 1875 ( $O$ Globo, 21 dez. 1875). Cony Júnior fundou um grupo de teatro amador, um ano antes do pai morrer, chamado Grupo Dramático de Ouro, com sede na chácara de sua residência. Era "diretor de cena" e os membros do grupo, com pelo menos quatro da família de Cony, foram fotografados para compor um artigo da Gazeta de Notícias (29 jul. 1905).

Figura 31 - Artigo sobre o Grupo Dramático de Ouro, com sede na chácara da família Cony

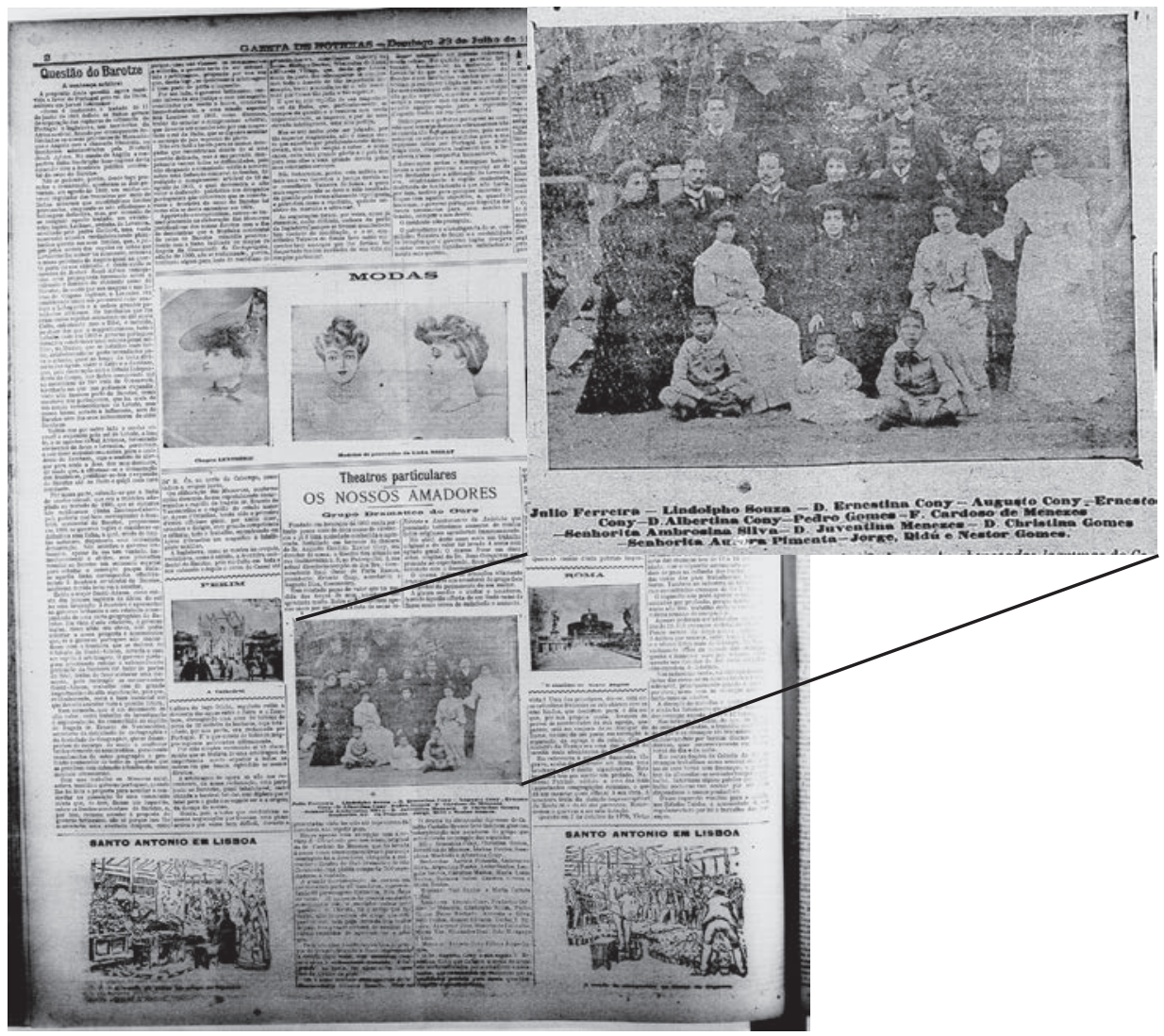

Fonte: Gazeta de Notícias, 29 jul. 1905, Biblioteca Nacional. 
O envolvimento do professor Augusto Cony com as atividades teatrais pode ter motivado o filho a se inserir no meio. Durante sua participação no Recreio Riachuelense, Cony teve participação direta na definição das encenações (Gazeta de Notícias, 30 nov. 1881): “A distinta sociedade particular Recreio Dramático Riachuelense dá, na noite de 3 de dezembro, uma recita, na qual se representará o drama Uma Paixão, extraído pelo Sr. Augusto Cony do romance do mesmo título". O que significaria "extraído"? Uma possibilidade seria a realização de adaptação da obra pelo professor para o formato do gênero teatral.

A Sociedade igualmente serve de exemplo de que as questões políticas também aparecem sobremaneira nos espaços de lazer. Enquanto Cony, ligado ao Partido Liberal, atuava na parte teatral da Sociedade, o mesmo espaço foi lugar da reunião de eleitores da freguesia do Engenho Novo, em 1882 (AL, 1882), grupo do qual Pardal fazia parte. Também no teatro, tomou posse a diretoria da Associação Libertadora Visconde do Rio Branco da qual Pardal se tornou presidente e que, em discurso, propôs a mudança do nome para Sociedade Abolicionista Visconde do Rio Branco (Gazeta da Tarde, 04 jun. 1883; 07 jun. 1883), como dissemos. Assim como no caso do Club Mozart o lugar era usado para reuniões de outros tipos que não as recreativas.

Tais aspectos não devem ser encarados como mera coincidência. Não dispomos de mais informações que assinalem o processo que levou à instalação de reuniões de professores em espaços pertencentes a uma instituição de atividade distinta como as recreativas e literárias. No entanto, os sujeitos que transitam por tais lugares devem ser considerados nos processos de agência e articulação social, política e profissional que demandam a mobilização de espaços, pessoas e instituições. Desse modo, cabe demonstrar a lista de instituições, levantada de forma não exaustiva, das quais os professores fizeram parte:

Quadro 25 - Instituições recreativas e literárias

\begin{tabular}{|c|l|l|}
\hline N. & Nome & Posição \\
\hline 1 & $\begin{array}{l}\text { Luiz Thomaz de } \\
\text { Oliveira }\end{array}$ & Procurador da Sociedade Campestre (Correio Mercantil, 15 abr. 1860). \\
\hline 2 & José Alves da Visitação & Reunião da Sociedade Alfa Literária (O Globo, 19 out. 1874). \\
\hline 3 & $\begin{array}{l}\text { Carlos Antonio Coim- } \\
\text { bra de Gouvea }\end{array}$ & Presidente da Sociedade Alfa literária (O Globo, 12 out. 1874). \\
\hline 4 & José Bernardes Moreira & Sociedade Alfa Literária (O Globo, 29 nov. 1875). \\
\hline
\end{tabular}




\begin{tabular}{|c|l|l|}
\hline 5 & Luiz Augusto dos Reis & Sociedade Alfa Literária (O Globo, 29 nov. 1875). \\
\hline 6 & $\begin{array}{l}\text { Francisco Alves da } \\
\text { Silva Castilho }\end{array}$ & $\begin{array}{l}\text { Discurso na inauguração da Sociedade - Instituto Filarmônico (O } \\
\text { Apóstolo, 27 fev. 1870). }\end{array}$ \\
\hline 7 & $\begin{array}{l}\text { Antonio Cypriano de } \\
\text { Figueiredo Carvalho }\end{array}$ & $\begin{array}{l}\text { Primeiro secretário do Instituto Filológico Brasileiro (Jornal da Tarde, 27 } \\
\text { abr. 1877); . }\end{array}$ \\
\hline 8 & $\begin{array}{l}\text { Manoel José Pereira } \\
\text { Frazão }\end{array}$ & Presidente da Sociedade Brasileira Ensaios literários (AL, 1868). \\
\hline 9 & $\begin{array}{l}\text { Jose Joaquim Pereira de } \\
\text { Azurara }\end{array}$ & Secretário da Sociedade Musical Rio-Pretana (AL, 1866). \\
\hline 10 & $\begin{array}{l}\text { Augusto Candido } \\
\text { Xavier Cony }\end{array}$ & $\begin{array}{l}\text { Comissão de contas do Recreio Dramático Riachuelense (O Cruzeiro, } \\
13 \text { jun. 1878); sócio da Associação Literária Gonçalves Dias (O Paiz, 04 } \\
\text { nov. 1884); sócio benemérito do Congresso Juvenil Literário (O Paiz, 18 } \\
\text { dez. 1885). }\end{array}$ \\
\hline 11 & $\begin{array}{l}\text { Januário dos Santos } \\
\text { Sabino }\end{array}$ & $\begin{array}{l}\text { Membro efetivo da Academia filosófica (AL, 1856); redator de jornal } \\
\text { literário chamado Cysne (Constitucional, 19 maio 1864). }\end{array}$ \\
\hline 12 & Gustavo José Alberto & Tesoureiro do Club Mozart (AL, 1884). \\
\hline
\end{tabular}

Fonte: Quadro elaborado pela autora com base nas informações levantadas nos jornais da Hemeroteca Digital da Biblioteca Nacional e no Almanak Laemmert.

A Sociedade Alpha Literária, por exemplo, havia sido fundada por professores, quatro dos quais listados no quadro acima - Carlos Antonio Coimbra de Gouvea, José Alves da Visitação, José Bernardes Moreira, Luiz Augusto dos Reis -, com o fim, segundo o estatuto de 1871 , de "desenvolver e cultivar a inteligência dos sócios".

Silva (2007, p. 10) afirma que "o desenvolvimento desses clubes se dá em paralelo ao declínio das reunióes dentro do lar, já que se cria um ambiente próprio à discussão, à audição, aos jogos e à leitura”. Podemos observar igualmente que emergiram como espaços onde professores buscavam um momento para recreação e que, ao mesmo tempo, poderiam funcionar como lugar importante de desenvolvimento de sociabilidades e experiências diversas. Nesse sentido, música, teatro, literatura e demais atividades de caráter recreativo poderiam ser espaços para o lazer como também para fazer política, movimentos sociais e reuniões profissionais, aparentemente alheias ao espaço de diversão, mas com várias conexões.

Os dados mostram que os professores públicos primários, longe de viverem na obscuridade, como acreditava Almeida de Oliveira em 1873 (2003), possuíam uma inserção variada e bastante ativa na sociedade. Nota-se que tanto o governo quanto a população reconheciam no professor uma figura importante 
nos processos sociais, podendo auxiliar tanto o governo na tarefa de administrar a sociedade quanto nas associações de iniciativa popular ou elitizada. Cabe assinalar que, nas notas e publicidade das sociedades nos jornais, era comum, ao mencionarem os nomes de seus membros, indicar antes do nome completo a condição de professor. Isso aponta que o processo de profissionalização docente também pode passar pelo reconhecimento da sociedade. Contar com professores públicos primários em seus quadros, poderia conferir mais legitimidade às instituições, auxiliar sua organização e o cumprimento de seus objetivos.

De uma maneira bastante heterogênea, observamos professores envolvidos em abaixo-assinados tanto para resolução de problemas locais, quanto de maior alcance geográfico, em favor da eleição de políticos; na organização de comissões contra a supressão de trens do subúrbio, quanto em comissões da Sociedade Auxiliadora da Indústria Nacional. A atuação e a experiência de professores como sócios, conselheiros e administradores mostram um protagonismo docente na cidade, exercido em diferentes níveis de atuação, instituições e intensidade diversas. De uma forma geral, os professores estavam envolvidos com a ordem, a política, economia, a beneficência, a religiosidade e o lazer na cidade. Apesar dos baixos salários, os professores usavam estratégias variadas e fugiam da representação de um professor passivo, recatado, que teria como única dedicação o ensino. 